\title{
RAPID ADJUSTMENT OF SUBMARINE CHANNEL ARCHITECTURE TO CHANGES IN SEDIMENT SUPPLY
}

$\underline{\text { Zane R. Jobe }}{ }^{1}$, Zoltán Sylvester ${ }^{1,3}$, Andrew O. Parker ${ }^{2}$, Nick Howes ${ }^{1}$, Niall Slowey ${ }^{2}$, Carlos $\underline{\text { Pirmez }^{1}}$

1. Shell Projects and Technology, 3333 Hwy 6 South, Houston, TX 77082, U.S.A.

2. Department of Oceanography, Texas AandM University, College Station, TX 77843, U.S.A.

3. Present address: Chevron Energy Technology Company, 1500 Louisiana St., Houston, TX 77002, U.S.A.

\section{ABSTRACT}

Changes in sediment supply and caliber during the last $\sim 130$ ka have resulted in a complex architectural evolution of the Y channel system on the western Niger Delta slope. This evolution consists of four phases, each with documented or inferred changes in sediment supply. Phase 1 flows created wide $(1,000 \mathrm{~m})$, low-sinuosity (1.1) channel forms with lateral migration and little to no aggradation. During Phase 2, the $\mathrm{Y}$ channel system began to aggrade, creating more narrow (300 m) and sinuous (1.4) channel forms with many meander cutoffs. This system was abandoned at $\sim 130 \mathrm{ka}$, perhaps related to rapid relative sea-level rise during MIS (Marine Isotope Stage) 5. Phase 3 flows were mud-rich and deposited sediment on the outer bends of the channel form, resulting in the narrowing (to $250 \mathrm{~m}$ ), straightening (to a sinuosity of 1.22), and aggradation of the $\mathrm{Y}$ channel system. Renewed influx of sand into the $\mathrm{Y}$ channel system occurred with Phase 4 at $\sim 50 \mathrm{ka}$, during MIS 3 sea-level fall. The onset of Phase 4 is marked by the initiation of the $\mathrm{Y}^{\prime}$ tributary channel, which re-established sand deposition in the $\mathrm{Y}$ channel system. Flows entering the $\mathrm{Y}$ channel from the $\mathrm{Y}^{\prime}$ channel were underfit, resulting in inner levee deposition that is most prevalent on outer banks, acting to further straighten (1.21) and narrow (to $200 \mathrm{~m}$ wide) the $\mathrm{Y}$ channel. The inner levees accumulated quickly as the flows sought equilibrium, with deposition rates $>200 \mathrm{~cm} / \mathrm{ky}$. Marked by the presence of the last sand bed, abandonment occurred at $\sim 19 \mathrm{ka}$ in the $\mathrm{Y}$ channel and $\sim 15 \mathrm{ka}$ in the $\mathrm{Y}^{\prime}$ channel and is likely related to progressive abandonment due to shelf-edge delta avulsion and/or progressive sea level rise associated with Melt Water Pulse 1-A. The muddy, 5-meter-thick Holocene layer has thickness variations that mimic those seen in the sandy part of Phase 4, suggesting that dilute, muddy flows continue to affect the modern $\mathrm{Y}$ channel system. This unique dataset allows us to unequivocally link changes in submarine channel architecture to variations in sediment supply and caliber. Changes in the updip sediment routing system (i.e. the channel "plumbing") are shown to have profound implications for submarine channel architecture and reservoir connectivity.

\section{INTRODUCTION}


The nature of sediment supply plays an important role in determining the morphology and architectural evolution of siliciclastic depositional systems. In alluvial systems, sediment supply can impact the dimensions, morphology, and stability of channels (e.g., Harvey, 1991). Changes in channel dimensions, kinematics, alluvial cover, and incision rates have been linked to variations in sediment supply for modern rivers (Massong and Montgomery, 2000) as well as experimental fluvial channels (Finnegan et al., 2007). Shoreline and delta architecture and progradation rates are strongly influenced by temporal and spatial changes in sediment supply (Yang et al., 2003).

Sediment gravity flows, predominantly turbidity currents, sculpt the seafloor by erosion and deposition into dramatic seascapes, including deeply incised submarine canyons (Paull et al., 2011), sinuous submarine channels with numerous meander cutoffs (Antobreh and Krastel, 2006; Kolla et al., 2012), and submarine fans consisting of lobes and distributary channels (Deptuck et al., 2008; Jegou et al., 2008). The architecture of these depositional systems is strongly influenced by the input grain-size distribution (e.g., sand-rich vs. mud-rich systems of Reading and Richards, 1994). A more recent example from the Canadian Grand Banks highlights the difference between submarine canyons fed by sand- and gravel-rich glacial outwash and those fed solely by muddy slope failures (Armitage et al., 2010). Jobe et al. (2011) demonstrate that variations in sediment supply and grain-size distribution over millions of years have a clear impact on submarine canyon and channel architecture. Sediment supply, as in subaerial systems, must play a key role as well in the architectural evolution of submarine depositional systems. Many studies have documented sediment-supply-induced changes in submarine channel and fan activity (Covault et al., 2007; Romans et al., 2009; Paull et al., 2010, 2011). However, few studies have been able to constrain changes in the architecture of deep-water depositional systems caused by variations in sediment supply (Piper et al., 1999). This is especially difficult to do in outcrop and core studies, where shale drapes and erosional surfaces are often interpreted as signs of channel abandonment and reoccupation, but, due to the lack of three-dimensionality and fine-scale age control, it is impossible to verify whether that is indeed the case. The integration of high-resolution bathymetry, high-resolution "chirp" seismic reflection surveys, and core data has provided new insights into the architecture and evolution of submarine channel systems (Pirmez et al., 1997; Gervais, 2002; Babonneau et al., 2002, 2004, 2010; Paull et al., 2011). The absence, however, of three-dimensional (3D) seismic reflection data often hampers the understanding of the $3 \mathrm{D}$ complexity of these systems. This study combines conventional industry 3D seismic reflection data, high-resolution multibeam bathymetry, very-high-resolution 2D chirp seismic reflection data, and piston cores from the western Niger Delta slope to demonstrate profound changes in submarine channel architecture. These changes were likely caused by variations in sediment supply over time scales of $10^{3}-10^{5}$ years. The multi-scale approach also provides constraints on the spatial and temporal causes for variations in sediment supply (e.g., submarine channel drainage capture, relative sea-level fluctuations).

\section{NIGER DELTA}


The Niger Delta is one of the largest deltas in the world, with subaerial and submarine sediments covering an area of $\sim 140,000 \mathrm{~km}^{2}$, and $12 \mathrm{~km}$ in thickness (Allen, 1964, 1965; Evamy et al., 1978; Doust and Omatsola, 1989). Rapid Neogene sedimentation and the associated progradation have produced gravity-induced deformation of the delta and its submarine slope, resulting in a progressive downslope change from extensional, listric growth faults into a translational zone with shale diapirs and finally a compressional zone of imbricate toe thrusts (Damuth, 1994). The Niger River distributes mud to gravel-size sediment onto the delta from a drainage area of $1.2 \times 10^{6} \mathrm{~km}^{2}$, and the Niger River's mean annual discharge and sediment load are $6,140 \mathrm{~m}^{3} / \mathrm{s}$ and $1,270 \mathrm{~kg} / \mathrm{s}$, respectively (Mulder and Syvitski, 1995). The Forcados/Ramos and Sangana/Nun distributary systems split the Niger River discharge in roughly equal portions onto the western and southern portions of the Niger Delta (Allen, 1965) (Fig. 1).

\section{STUDY AREA}

The study area is located $55 \mathrm{~km}$ from the shoreline on the continental slope of the western Niger Delta, in water depths ranging from $120 \mathrm{~m}$ to $1570 \mathrm{~m}$ (Figs. 1, 2). This area occupies the "translational" structural regime of Damuth (1994), where shale diapirs and ridges are common (Fig. 2). Pirmez et al. (2000) first studied the modern turbidite depositional systems (Fig. 1) and identified three main channels, the X, Y, and $\mathrm{Y}^{\prime}$ channels (Fig. 2). The $\mathrm{X}$ channel flows southwest for $\sim 80 \mathrm{~km}$ from the shelf edge before terminating in a lobate sand-rich body (Fig. 3). The X channel and lobe was the focus of a study by Prather et al. (2012), who interpret this system as a "perched apron" with a ponded phase followed by deposition in healed-slope accommodation (see their Fig. 20). The $\mathrm{Y}$ channel is located just south of the $\mathrm{X}$ channel and lobe (Figs. 1, 2) and flows westward for more than $70 \mathrm{~km}$ before exiting the study area. A downslope segment of the same channel and its interaction with fold growth was studied by Heiniö and Davies $(2006,2007)$. The downslope extent of the $Y$ channel system is not known, but presumably it terminates in a base-of-slope submarine fan. The $\mathrm{Y}^{\prime}$ channel is located between the $X$ and $Y$ channels and flows southwestward until being captured by the $Y$ channel (Fig. 2). Downstream of the $\mathrm{Y}^{\prime}$ junction, the $\mathrm{Y}$ channel has a well-defined thalweg and numerous terraces (Fig. 3); in contrast, upstream of the $\mathrm{Y}^{\prime}$ junction, the thalweg is discontinuous and has numerous ridges and intra-channel pockmarks, suggesting recent channel abandonment (Fig. 3; Pirmez et al., 2000; cf. Jobe et al., 2011).

\section{DATASET}

\section{Remotely Sensed Data}

Approximately $8,800 \mathrm{~km}^{2}$ of three-dimensional (3D) seismic reflection data were available for this study, and $400 \mathrm{~km}^{2}$ were interpreted in detail (Figs. 2, 3). Both high-resolution and low-resolution surveys cover the study area, although most interpretation was done on the high-resolution survey. Both surveys are pre-stack time-migrated, zero phase, and SEG reverse polarity (i.e., seafloor is a negative reflection / trough). Bin spacing (i.e., horizontal resolution) is 
$12.5 \mathrm{~m} \mathrm{x} 12.5 \mathrm{~m}$ and $18.75 \mathrm{~m} \mathrm{x} 12.5 \mathrm{~m}$ for the high-resolution and low-resolution surveys, respectively. The dominant frequency is 100 and $60 \mathrm{~Hz}$ for the high-resolution and lowresolution surveys, respectively, resulting in vertical resolution of $5 \mathrm{~m}$ and $8.3 \mathrm{~m}(1 / 4$ wavelength using $2000 \mathrm{~m} / \mathrm{s}$ velocity for shallow subsurface).

An underwater autonomous vehicle (AUV) survey in November 2012 yielded very-highresolution data in a focus area (Fig. 3b, 4). The "SV Echo Surveyor IV," a Hugin 1000 AUV, flew 24-35 $\mathrm{m}$ above the seafloor, collecting the following:

1. $12 \mathrm{~km}^{2}$ multibeam bathymetry and backscatter data (gridded at $1.5 \mathrm{~m}$ bin spacing) from a Kongsberg Simrad EM2040 300 kHz multibeam echo sounder (Fig. 4);

2. 124 line km of very-high-resolution 2D sub-bottom profiles from an Edgetech DW-106 chirp sub-bottom profiler operating at frequencies of 1-6 kHz, resulting in an estimated vertical resolution of $0.2 \mathrm{~m}$.

3. $12 \mathrm{~km}^{2}$ side-scan sonar data from an Edgetech Deep Water Full Spectrum chirp dual frequency $105 / 410 \mathrm{kHz}$ side-scan sonar system with $0.25 \mathrm{~m}$ resolution.

\section{Core Data}

Forty-two four-inch jumbo piston cores and 18 three-inch piston cores were taken in the study area by TDI-Brooks in December 2007 (Figs. 3, 4), and this study focuses on 24 of those cores (Fig. 4). The total length of the 24 cores is $223.7 \mathrm{~m}$, and core recovery averages $9.3 \mathrm{~m}$. Core descriptions were digitized and tabulated in order to evaluate trends in bed thickness and grain size. More than 400 grain-size samples were analyzed using a Malvern Mastersizer 2000 particle-size analyzer in order to obtain grain-size distributions from the core data.

\section{Radiocarbon Age Dates}

Samples were taken from $6 \mathrm{~cm}$ intervals in the cores and trimmed to avoid drag-induced contamination from the core edges. These samples were washed and sieved, and the residue was picked to obtain $10 \mathrm{mg}$ of Globigerinoides ruber. When G. ruber wasn't abundant in a sample, a mixed planktic assemblage was picked. The samples were analyzed at the Center for Accelerated Mass Spectrometry at the Lawrence Livermore National Laboratory. Radiocarbon ages were then converted to calendar age using Calib 7.0 (Stuiver et al., 2005) and a standard marine reservoir age correction of 400 years. All quoted ages are in radiocarbon years using the Libby half-life of 5568 years and following the conventions of Stuiver and Polach (1977). Table 1 displays the uncorrected and corrected ages with other pertinent data.

\section{PHASES OF CHANNEL DEVELOPMENT IN THE Y CHANNEL SYSTEM}

\section{Previous Channel Systems}


At least two channel systems pre-date the formation of the Y channel system (Fig. 5), but neither affects current seafloor topography (Fig. 3). The older of the two systems occurs directly below the modern channel system, its base $\sim 1000 \mathrm{~m}$ below the seafloor (Fig. 5). This system is $\sim 400 \mathrm{~m}$ thick and $4 \mathrm{~km}$ wide and consists of large mass-transport deposits (MTDs) and channelfill deposits. Dipping reflectors on the northern margin have been postdepositionally modified by shale diapirism (Fig. 5). The younger of the two systems is located $1 \mathrm{~km}$ south of and at approximately the same elevation as the modern channel system. It displays large external levees, a lower, high-amplitude channel fill, and an upper, low-amplitude (abandonment) channel fill (Fig. 5). Any coeval levee deposits to the north have been eroded by the modern Y channel system (Fig. 5).

\section{Evolution of the Y Channel System}

The Y channel system is the modern channel system on the seafloor and the focus of this study (Fig. 2, 3). The evolution of the Y channel system can be characterized by 4 phases (Fig. 6):

- Phase 1: Wide, degradational, low-sinuosity channel form

- Phase 2: Narrow, aggradational, high-sinuosity channel form with abundant meander cutoffs

- Phase 3: Progressive abandonment of the Y channel resulting in channel straightening

- Phase 4: Further narrowing and straightening due to the reoccupation of the Y channel by the $\mathrm{Y}^{\prime}$ channel

\section{Phase 1 - Wide, Degradational, Low-Sinuosity Channel Form}

Poor seismic resolution at depth combined with the complex topography that was inherited by prior channel systems limits efforts to characterize the initiation of the Y channel system. A period of widespread erosion must have predated Phase 1, but deposits from such phases have little chance for preservation (Sylvester et al., 2011). Phase 1 is the earliest mappable phase, and consists of large-scale lateral migration packages (ca. $120 \mathrm{~m}$ thick and 800 $\mathrm{m}$ wide; Fig. 7), similar in dimensions to those observed in the modern Bengal submarine channel (Kolla et al., 2012). The channel thalweg in Phase 1 is deepest on the outer bends, and shoals towards the laterally accreting inner bank (Fig. 7). No core data from Phase 1 are available, but high seismic amplitudes in the basal portions of the lateral-migration packages suggest sand-rich fill and low amplitudes in the upper portion are likely mud-rich (Fig. 7). This facies segregation is common in lateral-migration packages (Abreu et al., 2003; Dykstra and Kneller, 2009). A channel form at the top of Phase 1 was mapped and is shown in Figure 6A; the 
channel is low sinuosity $(1.1)$ and wide $(\sim 1,000 \mathrm{~m})$, markedly contrasting with the channel on the modern seafloor (Fig. 2).

Large mass-wasting features are prominent on the margins of the Y channel belt (Fig. 5), and were likely initiated during undercutting of the channel-margin substrate. These features are "rotated channel-margin slides" (Sawyer et al., 2007; Jobe et al., 2011) and show progressive rotation on a listric fault surface with up to $150 \mathrm{~m}$ of offset (see marker horizon in Fig. 5) that indicate synsedimentary deformation. Some of the crescent-shaped edges on the seafloor (Figs. 2,3 ) denote the subsurface locations of these slides, and also indicate that these slides are still active and are likely conveying pore fluids to the seafloor. In some locations, the rotated channel-margin slides seem to have prevented lateral channel migration, resulting in forced aggradation of future phases (Fig. 5; cf. Jobe et al., 2011). Similar features have been described in the nearby Benin-major canyon (Deptuck et al., 2007).

\section{Phase 2-High-Sinuosity, Aggradational Channel with Meander Cutoffs}

Phase 2 records the development of higher sinuosity and increased aggradation (Figs. 6C, 8). A preserved channel form at the top of Phase 2 was mapped to illustrate the geometry and architecture (Fig. 6C). The mapped channel form has a sinuosity of 1.35 and average width of $300 \mathrm{~m}$ (Fig. 6C). Lateral migration of Phase 2 channel forms produced numerous meander cutoffs, most of which are sand-filled (Figs. 8, 9). Some of these cutoffs truncate the Top Phase 1 channel form (e.g., Fig. 5). Considerable aggradation during subsequent phases resulted in the preservation of these cutoffs as flat terraces along the edges of the modern channel, with scalloped-shaped boundaries away from the axis (Fig. 6B, 6C). These arcuate terraces remain visible on the modern seafloor (Figs. 3, 6G) and are sites of inner levee deposition (cf. Deptuck et al., 2003, 2007). Phase 2 cutoffs and channel fill produce an irregular thickness pattern for Phase 2 deposits, with areas of decreased thickness associated with meander cutoffs (Fig. 6B).

\section{Phase 3 - Straightening and Narrowing of the Y Channel}

Phase 3 results in the straightening of the channel planform (Fig. 6E) and a significant narrowing of the channel (Fig. 7). Sinuosity is reduced from 1.4 at the Top Phase 2 surface to 1.22 at the Top Phase 3 surface (Fig. 6). This straightening and narrowing coincides with $\sim 50 \mathrm{~m}$ of aggradation (Figs. 5, 6D, 7). The lowermost channel-fill deposits of Phase 3 are characterized by high-amplitude reflectors that dip towards the outer bank (Fig. 9), likely due to lateral migration of the channel form. These high amplitudes suggest that the deposits are sand-rich and part of an active channel fill. However, most of the Phase 3 deposits are low-amplitude reflectors that dip towards the inner bank (Figs. 9, 10), suggesting mud-rich abandonment fill. These reflectors have a geometry that indicates "plastering" against the outer bank, causing straightening of the channel-form. A thickness map of Phase 3 (Fig. 6D, 9A) shows a consistent pattern of thick deposits near the outer bank of the channel and thin deposits near the inner bank. The preferential deposition on the outer bank acts to straighten the channel during Phase 3 (Fig. 
9). Most of the straightening occurs during deposition of the upper, low-amplitude channel fill (Fig. 9). Oxygen isotope dating in the g21 core (Fig. 11) matched to the LR04 benthic stack (Lisiecki and Raymo, 2005) indicates that the Top Phase 3 surface occurs at $\sim 130 \mathrm{ka}$.

\section{Phase 4 - Channel Narrowing, Straightening by Inner Levee Deposition and $Y^{\prime}$ Channel Initiation}

Phase 4 begins $\sim 40 \mathrm{~m}$ below the seafloor and is well imaged by both 3D seismic and chirp profiles, and piston cores up to $18 \mathrm{~m}$ long provide lithologic and age control. Phase 4 consists of limited (5-10 m) incision into the uppermost Phase 3 deposits and the buildup of significant (up to $30 \mathrm{~m}$ thick) inner levees inside the Phase 3 "container" (Fig. 10). The term "inner levee" in this paper denotes overbank deposits that are confined within a larger container (cf. Deptuck et al., 2003, 2007); synonymous terms are "internal" and "confined" levees (Kane et al., 2007; Kane et al., 2009; Kane and Hodgson, 2011) and "margin" (Hubbard et al., 2014). Conversely, outer or external levees act to confine the larger container, and have quite different morphologies and facies architecture (Deptuck et al., 2003), although they may be in part coeval with the inner levees (Sylvester et al., 2011). The Y channel fill consists of thick-bedded (typically $>30 \mathrm{~cm}$ thick) medium- to coarse-grained sands, and the inner levees consist of thinbedded (typically $<10 \mathrm{~cm}$ thick), fine-grained $\mathrm{T}_{\mathrm{bc}}$ and $\mathrm{T}_{\mathrm{c}}$ turbidites and interbedded mudstones (Figs. 11, 12). Core penetrations demonstrate that both bed thickness and grain size decrease with distance above the channel thalweg and laterally away from the channel centerline (Figs. $11 \mathrm{C}, 12$ inset). The inner levees are wedge shaped and thin rapidly away from the channel (Figs. 10, 11). In high-sinuosity reaches, inner levees are preferentially developed on the outer bends of the channel (Fig. 6F), which acted to straighten the channel and therefore steepen the channel thalweg gradient. Similar deposits on the outer bends of submarine channels have been described by Janocko et al. (2013a, 2013b) as “outer-bank bars". In low-sinuosity and straight reaches, the inner levee thickness pattern is not as consistent, and the thicker inner levee can be located on the outer bend (Fig. 11) or can be symmetrical, building up evenly on both sides of the channel (Fig. 10). This is likely because the low-sinuosity bends are not tight enough to induce enhanced deposition on the outer bank.

Radiocarbon dating of Phase 4 indicates that inner-levee development began at $\sim 50 \mathrm{ka}$ (Figs. 11, 12). Sedimentation rates of the inner levees can be greater than $200 \mathrm{~cm} / \mathrm{ky}$ and decrease with distance from the channel thalweg (Figs. 11C, 12). The last occurrence of sand in the $\mathrm{Y}$ channel system occurs at $19 \mathrm{ka}$ (Figs. 11-13). Overlying the last sand is a $\sim$-m-thick muddy layer (Figs. 11-13) that exhibits substantial thickness variations (Fig. 14). Thickness patterns mapped from chirp profiles clearly indicate that this muddy layer is not an end-member hemipelagic drape with constant thickness everywhere, but instead mimics the thickness patterns seen in the sandy deposits of Phase 4 (Fig. 14). This layer, like the sand package below it, is thickest on inner-levee terraces, particularly in outer-bend locations, and thinnest on upstreamfacing slopes. This thickness pattern suggests that muddy turbidity currents are still flowing 
down the $\mathrm{Y}^{\prime}$ and $\mathrm{Y}$ channels, and perhaps are reacting in a similar way to the changes in crosssectional area that the sandier flows were prior to $19 \mathrm{ka}$.

The $\mathrm{Y}^{\prime}$ channel was initiated during Phase 4, and its deposits are laterally correlatable to the mappable Phase 4 surface in the Y channel (Fig. 15). The location of the $Y^{\prime}$ channel was likely influenced by the surface topography created by an underlying channel system and associated mass transport deposit (Fig. 16; cf. Armitage et al., 2009). The Y' channel is "weakly confined" (e.g., McHargue et al., 2011), having a broad shallow thalweg (Fig. 16B) or multiple thalwegs (Fig. 16C) that are sand-prone (Figs. 16D). Poor core recovery prevents full characterization of Phase 4 deposits in the $\mathrm{Y}^{\prime}$ channel, but sand in both the channel thalweg and overbank areas indicates that the channel was active from at least $28 \mathrm{ka}$ to $15 \mathrm{ka}$ (Fig. 8D). The last occurrence of sand in the $\mathrm{Y}^{\prime}$ channel occurs at $15 \mathrm{ka}$ (Fig. 16), 5 ka later than in the downstream Y channel. Upstream of the $\mathrm{Y}^{\prime}$ confluence, the $\mathrm{Y}$ channel exhibits low amplitudes (Fig. 15) and an ill-defined thalweg (Fig. 3), indicating channel abandonment. Conversely, the Y channel downstream of the $\mathrm{Y}^{\prime}$ confluence has a well-defined thalweg with high amplitudes (Fig. 15), indicating an active channel with flows sourced from the $Y^{\prime}$ channel. The active portion of the $\mathrm{Y}$ channel (downstream of the $\mathrm{Y}^{\prime}$ confluence) is much narrower than the abandoned segment due to the growth of inner levees during Phase 4 (Fig. 15). The timing of the inner-levee growth in the $\mathrm{Y}$ channel coincides with the initiation of the $\mathrm{Y}^{\prime}$ channel (Figs. 15, 16), thus constraining the timing of reoccupation.

\section{Y Channel System: Summary}

The initiation of the Y channel system cannot be mapped due to lack of preservation, poor seismic resolution at depth, and complex topography associated with earlier channel systems. Phase 1 of the Y channel system consists of large, low-sinuosity channel forms with lateral migration and degradation. Phase 2 records the transition to aggradation of smaller, highly sinuous channel forms with many meander cutoffs. Phase 3 records the progressive abandonment of the Y channel, and outer bank "plastering" of mud-rich flows leads to the straightening and narrowing of the channel form. Phase 4 represents the reoccupation of the $Y$ channel by sandrich flows sourced from the $\mathrm{Y}^{\prime}$ channel, resulting in inner-levee deposition (most prevalent on the outer banks) that further straighten and narrow the channel. The latest channel abandonment (marked by the last sand in cores) occurs during deglaciation, around $19 \mathrm{ka}$ in the $\mathrm{Y}$ channel and $15 \mathrm{ka}$ in the $\mathrm{Y}^{\prime}$ channel. The muddy Holocene layer is approximately $5 \mathrm{~m}$ thick and mimics the thickness patterns seen in the sandy part of Phase 4.

\section{DISCUSSION}

\section{Architectural Response to Changing Sediment Supply and Caliber}

Submarine-channel initiation and incision is associated with periods of high sediment supply (Elliott, 2000; Smith et al., 2007; Conway et al., 2012; Biscara et al., 2013). The development of large entrenched submarine channel systems (i.e., valleys) like the Y channel 
system has been linked both to high sediment supply (Normark and Carlson, 2003) and to baselevel changes (McHargue et al., 2011; Sylvester et al., 2011, 2012). Cross-sectional area (CSA) is also a good proxy for sediment supply and flux. The relationship between sediment discharge and channel CSA is well established for rivers (Leopold and Maddock, 1953; Parker et al., 2007), but very little work has focused on these relationships for submarine channels. Pirmez and Imran (2003) calculate that sediment discharge decreases with decreasing CSA in the Amazon submarine channel (their Fig. 14). Konsoer et al. (2013) use a hydraulic geometry analysis to demonstrate that submarine channels and rivers have very similar relationships between CSA and discharge. The $\mathrm{Y}$ channel system exhibits temporal changes in cross sectional area and architecture (e.g., aggradation vs degradation, high sinuosity vs. low sinuosity) that are interpreted to be caused by variations in sediment supply and grain size. Although submarine channel systems often show a limited within-system variability of channel dimensions (e.g., Deptuck et al., 2003; Kolla et al., 2012) that likely reflects a lack of significant changes in the sediment supply (Sylvester et al., 2011), the example described here suggests that some slope channel systems are strongly affected by reorganizations in their "plumbing", resulting in changes to the size and composition of the channel-forming turbidity currents.

$\underline{\text { Phase } 1}$

There is abundant erosion observed in early Phase 1 deposits (Fig. 5) and the trajectory of the lateral migration deposits in Phase 1 (Fig. 7) is degradational, indicating downcutting of the channel thalweg though time. These data indicate that flows were eroding and bypassing sediment, a common observation in systems with high sediment supply. The Phase 1 channelform is also the widest mapped at 1,000 $\mathrm{m}$ wide (Figs. 6A, 7), indicative of high sediment discharge (cf. Konsoer et al., 2013). This high sediment supply could be related to climate, proximity of a shelf-edge delta, and/or tectonically induced changes in slope gradient (e.g., shale diapir movement). Unfortunately, uncertainty about the age of Phase 1 and the lack of sourcearea information preclude constraining the extrinsic control(s) on sediment delivery to the $\mathrm{Y}$ channel system during Phase 1.

$\underline{\text { Phase } 2}$

During Phase 2, the channel form narrowed from 1,000 $\mathrm{m}$ to $300 \mathrm{~m}$ and the sinuosity increased from 1.1 to 1.35 (Fig. 6). These changes in channel architecture are interpreted to have been caused by a decrease in sediment supply and flow discharge. The higher channel mobility during Phase 2 resulted in many cutoffs, most of which are neck cutoffs (Fig. 8). The location and orientation of the meander cutoffs with respect to the Top Phase 2 channel form (Fig. 8) suggests that most of these cutoffs occurred during aggradation. The similarity between the thalweg depths of the cutoffs and the Top Phase 2 channel form (Fig. 9) suggests that most cutoffs are only slightly older than the Top Phase 2 channel form. While many channelized environments tend to preserve meander cutoffs during degradation (e.g., Finnegan and Dietrich, 
2011), cutoffs that occur during aggradation are well documented in the Indus and Bengal submarine channel systems (Sylvester et al., 2011; Kolla et al., 2012).

$\underline{\text { Phase } 3}$

The gradual change from sandy, laterally migrating channel forms in early Phase 3 to mud-rich, outer-bank-biased deposits in late Phase 3 is likely related to the progressive abandonment of the $\mathrm{Y}$ channel. Upstream of the $\mathrm{Y}-\mathrm{Y}^{\prime}$ junction, the seafloor expression of the $\mathrm{Y}$ channel shows clear signs of abandonment (Fig. 3A), and seismic data suggest that it was abandoned during Phase 3 . The downstream reach of the $Y$ channel is only reoccupied by the $Y^{\prime}$ feeder channel with the initiation of Phase 4. The "plastering" of low-seismic-amplitude reflectors on the outer bank of the channel and the relatively uniform thickness of Phase 3 deposits across the $Y$ channel system suggests that Phase 3 flows were large, muddy, and relatively depositional turbidity currents. High suspended-load concentration within turbidity currents has been shown to lead to outer bank deposition in numerical (Das et al., 2004) and experimental (Straub et al., 2008) models. Kane et al (2008) found that large, out-of-equilibrium flows showed limited bypass and deposited preferentially on the outer bend. The associated decrease in sinuosity due to outer-bank deposition is also described by Janocko et al. (2013a).

Phase 4

During Phase 4, turbidity currents flowing through the $Y$ channel were sourced from the $\mathrm{Y}^{\prime}$ channel (Fig. 3). Thin sand deposits and radiocarbon ages from the a1, a3, and a4 cores indicate that flows in the $\mathrm{Y}^{\prime}$ channel were predominantly bypassing sediment (Fig. 16D), implying that flows were at quasi-equilibrium in the $\mathrm{Y}^{\prime}$ channel. However, the flows went out of equilibrium upon encountering a wider and deeper $Y$ channel (Fig. 15). These underfit Phase 4 flows eroded the $Y$ channel thalweg and locally deposited inner levees. Inner-levee deposition resulted in the decrease of the cross-sectional area (CSA) of the Y channel. Preferential deposition on the outer bends caused narrowing as well as straightening, which resulted in an overall steeper $\mathrm{Y}$ channel gradient, one more similar to that of the $\mathrm{Y}^{\prime}$ channel. These changes in channel architecture caused the CSA and thalweg gradient of the $Y$ channel to more closely resemble the $Y^{\prime}$ channel (Fig. 15). During Phase 4, the abandoned segment of the $Y$ channel (located upstream of the $\mathrm{Y}^{\prime}$ confluence) was draped with muddy sediments (Fig. 15) and modified by fluid expulsion, creating pockmarks and ridges (cf. Jobe et al., 2011). Downstream of the $Y^{\prime}$ junction, the $Y$ channel was active until $19 \mathrm{ka}$, when the entire $Y$ channel system was abandoned. Radiocarbon dating of the last occurrence of sand in multiple cores constrains the timing of modern abandonment in the $\mathrm{Y}$ channel to $19 \mathrm{ka}$ and the $\mathrm{Y}^{\prime}$ channel to $15 \mathrm{ka}$ (Figs. 1113, 16). The thickness pattern of the Holocene mud layer (Fig. 14) suggests that while sand is no longer being transported, muddy and dilute turbidity currents similar to late Phase 3 flows may still be flowing down the $\mathrm{Y}^{\prime}$ channel and the $\mathrm{Y}$ channel downstream of the $\mathrm{Y}^{\prime}$ confluence. 
Preferential deposition on the outer banks of submarine channels has been attributed to many different flow processes, including reverse secondary flow (Keevil et al., 2006), the influence of Coriolis force on the flow (Peakall et al., 2012), and inertial forces in disequilibrium flows (Abd El-Gawad et al., 2012, Janocko et al., 2013a). The influence of Coriolis is negligible for the $\mathrm{Y}$ channel system as the latitude of the channel system is $4.7^{\circ} \mathrm{N}$, and the Rossby number for these flows would be very large, indicating that centrifugal forces are much larger than Coriolis force (Sylvester et al., 2013). The influence of reverse secondary flow cannot be excluded, but data from numerical simulations on the seafloor bathymetry in the study area (Abd El-Gawad et al., 2012) suggest that complex bathymetry and sinuosity cause inertial forces to be dominant, precluding the development of significant secondary circulation. In contrast with the out-of-equilibrium and overall channel-straightening flows of Phase 4 and 3, previous periods of active channel migration and increasing sinuosity were dominated by deposition on the inner banks and - most probably - a near-bed secondary circulation with a normal, river-like orientation. The presence of numerous oxbow cutoffs in Phase 2 supports this inference (Figs. 8, 9).

\section{Changes in Cross-Sectional Area and Estimated Discharge}

Through each phase in channel evolution, there is a decrease in the size of the channel, as measured by width, depth, and CSA (Fig. 17). Other submarine channels display this motif as well (e.g., Indus channel, McHargue, 1991; West Africa, Janocko et al., 2013b). We interpret that the decreases in channel size in the $\mathrm{Y}$ channel system are linked to changing sediment supply through time. The Phase 1-2 transition results in a twofold decrease in CSA (Fig. 17). Poor seismic resolution and quality at this deeper level prevents us from identifying the reason for this change, but a decrease in the characteristic flow size is a likely explanation. However, the smaller-discharge flows of Phase 2 were still powerful enough to carve and maintain their own equilibrium channel, and this channel was active for long enough to create channel segments with high sinuosity and cutoffs. Although the origin of the abandonment-related Phase 3 flows is not unequivocally known, they must have had larger lateral extents and less stratification than the typical channel-shaping flows of the previous phase. These deposits led to a 1.2x decrease in CSA (Fig. 17). The 1.5x decrease in cross sectional area from Phase 3 to Phase 4 can be unequivocally linked to a change in the slope drainage network and the related change in sediment supply. After Phase 3 abandonment, the Y channel was reactivated during Phase 4 by flow capture through the $\mathrm{Y}^{\prime}$ channel (Fig. 14), causing straightening and narrowing of the channel form (Figs. 6,10). The CSA of the $\mathrm{Y}^{\prime}$ channel is half that of the $Y$ channel (Fig. 17), and thus flows deposited sediment to form inner levees, narrowing the $\mathrm{Y}$ channel. In some locales, more than $30 \mathrm{~m}$ of sediment were deposited in less than $5 \mathrm{ky}$ in order to construct these inner levees (Fig. 11), indicating that the flows were out of equilibrium with the $Y$ channel cross section. A more thorough and quantitative treatment of estimation of flow properties is underway using this unique, multi-scale dataset. 


\section{Causes Of Sediment-Supply Fluctuation and Timing of Sediment Delivery to the Y Channel System}

Changes in sediment supply have profoundly affected the architecture of the Y channel system during its history (Fig. 6). No data are available to constrain the timing of Phases 0 and 1. However, Phases 2-4 are well constrained, and here we discuss autogenic and allogenic causes for the observed changes in sediment supply and caliber. Extrapolation from the g21 oxygen isotope age record allows the estimation of the Top Phase 2 channel form to $130 \mathrm{ka}$ (Fig. 11). Early Phase 3 deposits are sandy, and were likely delivered while sea level was low during Marine Isotope Stage (MIS) 6. However, most of the Phase 3 deposits are mud-rich, suggesting that rapid sea-level rise during MIS 5 resulted in a decrease in sand supply to the Y channel system. Late Phase 3 mud-rich deposits accumulated in the Y channel system during the early half of the last glacial period (MIS 4 and 3) when sea level was at intermediate levels (Figs. 11, 18).

Progressive sea-level fall during MIS 3 (57-29 ka) increased the likelihood of bringing coarse clastic detritus back into the $\mathrm{Y}$ channel system (Fig. 19). The Top Phase 3 channel form (Fig. 6C) represents the moment of reoccupation, when the $\mathrm{Y}^{\prime}$ channel was created and reoccupied the downstream reach of the $\mathrm{Y}$ channel. Using radiocarbon and oxygen isotope methodologies in the g21 core, this renewed influx of sand into the $\mathrm{Y}$ channel occurred at $\sim 50$ ka (Fig. 18). Progressive sea-level fall during MIS 3 may have contributed to this reoccupation (Fig. 19); alternatively, an avulsion into the Forcados or Ramos tributaries of the Niger Delta (Fig. 1) may have brought sediment to the head of the $\mathrm{Y}^{\prime}$ feeder channel, which was likely located at the shelf edge at that time. Sand accumulated rapidly in the $\mathrm{Y}$ channel system during MIS 2, with thalweg and inner-levee sedimentation rates reaching $\sim 150 \mathrm{~cm} / \mathrm{ky}$ and $>200 \mathrm{~cm} / \mathrm{ky}$, respectively (Fig. 19), with an average rate of $159 \mathrm{~cm} / \mathrm{ky}$ (Fig. 18B). Rates of accumulation in the $Y^{\prime}$ channel, however, were much slower $(<50 \mathrm{~cm} / \mathrm{ky}$, Fig. 19), although poor core recovery prevents full characterization (Fig. 15).

Abandonment of the $\mathrm{Y}$ channel is dated by the last sand occurrence at $19 \mathrm{ka}$ (Fig. 19), during the last glacial maximum (LGM) and prior to rapid sea-level rise. The Y channel was abandoned abruptly during very low sea level state, suggesting that the abandonment may not have been caused by sea-level rise, a typical causal mechanism for Holocene submarine channel abandonment. No data are available on the age or exact location of shelf-edge deltas, but a deltalobe avulsion at 19 ka diverting sediment away from the $Y$ channel could justify the sudden sand cessation. Abandonment of the $\mathrm{Y}^{\prime}$ channel is poorly constrained due to poor core recovery, but the last sand deposited in the channel (a3 core, Fig. 15) could be as young as $15 \mathrm{ka}$, indicating that the $\mathrm{Y}$ channel system was progressively abandoned, and that the updip $\mathrm{Y}^{\prime}$ channel was abandoned after the $Y$ channel segment. Interestingly, the timing of $\mathrm{Y}^{\prime}$ channel abandonment corresponds approximately to Melt-Water Pulse 1-A ( $\sim 14.5 \mathrm{ka})$, a time when rates of sea-level rise exceeded $46 \mathrm{~mm} / \mathrm{yr}$ (Deschamps et al., 2012). During Melt-Water Pulse 1-A, sea level rose approximately $20 \mathrm{~m}$ in $~ 500$ years, from $110 \mathrm{~m}$ below present day sea level to nearly $90 \mathrm{~m}$. 
Given that the depth of the shelf edge off the western Niger Delta is approximately $100 \mathrm{~m}$, this rise in sea level could have submerged the shelf edge and abruptly shut down sand supply to the $\mathrm{Y}^{\prime}$ channel. Finally, the progressive updip abandonment seen from the $\mathrm{Y}$ channel to the $\mathrm{Y}^{\prime}$ channel is not surprising, as erosive flows in the upper reaches of submarine channels commonly do not propagate into the lower reaches (e.g., Paull et al., 2010). The rate of post-abandonment mud accumulation is $35 \mathrm{~cm} / \mathrm{ky}$ (Figs. 18B, 19), much more rapid than published rates of hemipelagic sediment accumulation (Stow et al., 2002). This supports the interpretation in Figure 14 that while sand is no longer being transported, muddy currents are still flowing down the Y channel system, delivering sediment onto inner levees.

\section{APPLICATION TO PREDICTION AND CHARACTERIZATION OF HYDROCARBON RESERVOIR}

The Bonga Field produces hydrocarbons from slope turbidites of Miocene age, just south of the Y channel system, in Block OML 118 (Chapin et al., 2002; Fig. 1). A significant proportion of the submarine-channel-related deposits are similar in scale and facies to those in the $\mathrm{Y}$ channel system, and they are relatively well imaged in 3D seismic data. A plan-view, same-scale comparison demonstrates that some of the out-of-channel deposits at Bonga are similar in size and shape to the Phase 4 inner levees in the Y channel system (Fig. 20A). Well and core data demonstrate that the reservoir facies are also similar (Fig. 20B). Thus, the wellimaged and well-understood $\mathrm{Y}$ channel system can be used to better predict hydrocarbon volumes and reservoir connectivity at Bonga and other comparable reservoirs, especially in the case of thinner-bedded and lower-net-to-gross facies, which are often ignored with current development strategies. For example, the inner-levee deposits of the Y channel are restricted to single meander bends, leading to limited lateral connectivity. Such individual "pods" of innerlevee deposits (Fig. 20A) have gross rock volumes of 2-4 x $10^{6} \mathrm{~m}^{3}$, and with typical reservoir properties would contain 0.5-2 million barrels of oil. In the deepwater offshore environment, these volumes are not attractive as drilling targets on their own, but if connected by channelfilling sands, these deposits can greatly contribute to existing production. Surface-based modeling techniques like those described in Sylvester et al. (2011) could be used to build highresolution static and dynamic models that would capture channel geometry and connectivity in a realistic fashion. Because the geometries and facies architecture at Bonga are similar to the Y channel system, invoking a similar style of evolution at Bonga is tempting. However, the creation of inner levees or terraces can be achieved by multiple processes, including sediment supply variations (this study), channel-form migration (Deptuck et al., 2007; Sylvester et al., 2011), thalweg incision (Babonneau et al., 2004), and channel-bank slumping (Kenyon et al., 1995). The data are not of sufficient resolution to determine which process is dominant at Bonga.

\section{CONCLUSIONS}

For the first time, we describe 3-D changes in submarine channel architecture that are unequivocally related to variations in sediment supply and caliber. Changes in sediment supply 
and caliber related to the updip sediment routing system (i.e., the channel "plumbing") during the last $150 \mathrm{ka}$ have produced profound changes in submarine channel architecture and reservoir connectivity in the Y channel system, located on the western Niger Delta slope. High-sedimentdischarge flows during Phase 1 created a wide $(1,000 \mathrm{~m})$, low-sinuosity $(1.1)$ channel form with lateral migration and degradation. During Phase 2, sediment discharge decreased, causing aggradation and the development of a narrow (300 $\mathrm{m}$ wide) and more sinuous (1.4) channel form with numerous meander cutoffs. Phase 3 marks the abandonment of the Y channel system at $130 \mathrm{ka}$, coincident with sea-level rise at MIS 5. Phase 3 is characterized by mud-rich deposits plastered to the outer bends of the channel form, resulting in further narrowing (to $200 \mathrm{~m}$ ) and straightening (to a sinuosity of 1.22) of the Y channel. Reoccupation of the Y channel system by sandy flows occurred at $\sim 50$ ka during MIS 3 sea-level fall and marked the onset of Phase 4 . The $\mathrm{Y}^{\prime}$ channel was initiated during Phase 4 and acted as the sole feeder channel to the $\mathrm{Y}$ channel system during that time. Flows entering the $\mathrm{Y}$ channel from the $\mathrm{Y}^{\prime}$ channel were underfit, resulting in inner-levee deposition that was most prevalent on the outer banks, acting to further straighten and narrow the Y channel. The inner levees accumulated very quickly as the flows sought equilibrium, with deposition rates exceeding $200 \mathrm{~cm} / \mathrm{ky}$. Abandonment of the Y channel occurred at $19 \mathrm{ka}$ and is likely related to a shelf-edge delta avulsion, although deglacial sea-level rise cannot be excluded. Abandonment of the $\mathrm{Y}^{\prime}$ channel occurred at $15 \mathrm{ka}$ and was likely related to rapid sea level rise associated with Melt Water Pulse 1-A. The Holocene postabandonment muddy layer mimics the thickness patterns seen in the sandy part of Phase 4, suggesting that dilute, muddy flows still sculpt the Y channel system.

Channels on large submarine fans like the Amazon, Zaire, Indus, and Bengal are likely to have a relatively stable sediment supply that results in limited temporal variability of the channel dimensions and channel architecture. In contrast, the channels described here are smaller and, along with their feeding shelf-edge sources, are frequently subjected to major changes in the nature of channel-forming gravity flows. This variability results in a more complicated and less predictable stratigraphic architecture and should be considered when assessing reservoir connectivity or reconstructing continental margin-evolution.

\section{ACKNOWLEDGEMENTS}

The authors would like to thank Shell International Exploration and Production and Shell Nigeria Exploration and Production Company for the permission to publish; Fugro for collection and processing of AUV data; Mary McGann and Diablo Valley Geological Services for processing of core samples, Tom Guilderson at Lawrence Livermore National Laboratory for radiocarbon dating, Texas AandM University for core storage and sampling materials, TDIBrooks for collection of core data. Ian Kane, Tim McHargue, and Bill McCaffrey provided insightful reviews that greatly improved the paper. Finally, this paper benefitted from discussions with Alessandro Cantelli, Daniel Minisini, Brad Prather, Matt Wolinsky, and John Martin.

\section{REFERENCES}


Abd El-Gawad, S.M., Pirmez, C., Cantelli, A., Minisini, D., Sylvester, Z., and Imran, J., 2012, 3D numerical simulation of turbidity currents in submarine canyons off the Niger Delta. Marine Geology, v. 326, p. 55-66.

Abreu, V., Sullivan, M., Pirmez, C., and Mohrig, D., 2003, Lateral accretion packages (LAPs): an important reservoir element in deep water sinuous channels. Marine and Petroleum Geology, v. 20, p. 631-648.

Allen, J.R.L., 1964, The Nigerian continental margin: bottom sediments, submarine morphology and geological evolution. Marine Geology, v. 1[4], p. 289-332.

Allen, J.R.L., 1965, Late Quaternary Niger delta, and adjacent areas: sedimentary environments and lithofacies. American Association of Petroleum Geologists Bulletin, v. 49[5], p. 547600.

Antobreh, A., and Krastel, S., 2006, Morphology, seismic characteristics and development of Cap Timiris Canyon, offshore Mauritania: a newly discovered canyon preserved-off a major arid climatic region: Marine and Petroleum Geology, v. 23, no. 1, p. 37-59, doi:10.1016/j.marpetgeo.2005.06.003

Armitage, D.A., Romans, B.W., Covault, J.A., and Graham, S.A., 2009, The influence of masstransport-deposit surface topography on the evolution of turbidite architecture: The Sierra Contreras, Tres Pasos Formation (Cretaceous), Southern Chile: Journal of Sedimentary Research, v. 79 [no. 5], p. 287-301, doi:10.2110/jsr.2009.035

Armitage, D.A., Piper, D.J.W., McGee, D.T., and Morris, W.R., 2010, Turbidite deposition on the glacially influenced, canyon-dominated Southwest Grand Banks Slope, Canada: Sedimentology, v. 57 [no. 6], p. 1387-1408, doi: 10.1111/j.1365-3091.2010.01149.x

Babonneau, N., Savoye, B., Cremer, M., and Klein, B., 2002, Morphology and architecture of the present canyon and channel system of the Zaire deep-sea fan: Marine and Petroleum Geology, 19(4), 445-467.

Babonneau, N., Savoye, B., Cremer, M., and Bez, M., 2004, Multiple terraces within the deep incised Zaire Valley (ZaïAngo Project): are they confined levees?, in Lomas, S.A. and Joseph, P., eds., 2004. Confined Turbidite Systems, Geological Society, London, Special Publication 222, p. 91-114.

Babonneau, N., Savoye, B., Cremer, M., and Bez, M., 2010, Sedimentary architecture in meanders of a submarine channel: detailed study of the present Congo turbidite channel (Zaiango project): Journal of Sedimentary Research, v. 80[10], p. 852-866.

Biscara, L., Mulder, T., Hanquiez, V., Marieu, V., Crespin, J. P., Braccini, E., and Garlan, T., 2013, Morphological evolution of Cap Lopez Canyon (Gabon): illustration of lateral migration processes of a submarine canyon. Marine Geology, v. 340, p. 49-56.

Covault, J.A., Normark, W.R., Romans, B.W., and Graham, S.A., 2007, Highstand fans in the California borderland: The overlooked deep-water depositional systems: Geology, v. 35[9], p. 783-786.

Chapin, M., Swinburn, P., Van der Weiden, R., Skaloud, D., Adesanya, S., Stevens, D., Varley, C., and Wilkie, J., 2002, Integrated seismic and subsurface characterization of Bonga Field, offshore Nigeria: The Leading Edge, v. 21, p. 1125-1131.

Conway, K.W., Barrie, J.V., Picard, K., and Bornhold, B.D., 2012, Submarine channel evolution: active channels in fjords, British Columbia, Canada. Geo-Marine Letters, v. 32[4], p. 301-312.

Damuth, J.E., 1994, Neogene gravity tectonics and depositional processes on the deep Niger Delta continental margin: Marine and Petroleum Geology, v. 11[3], p. 320-346. 
Das, H.S., Imran, J., Pirmez, C., and Mohrig, D., 2004, Numerical modeling of flow and bed evolution in meandering submarine channels: Journal of Geophysical Research: Oceans [1978-2012], v. 109, paper C10009, doi:10.1029/2002JC001518.

Deptuck, M., Steffens, G.S., Barton, M., Pimrez, C., 2003, Architecture and evolution of upper fan channel-belts on the Niger Delta slope and in the Arabian Sea: Marine and Petroleum Geology, v. 20, p. 649-676.

Deptuck, M.E., Sylvester, Z., Pirmez, C., and O'Byrne, C., 2007, Migration-aggradation history and 3-D seismic geomorphology of submarine channels in the Pleistocene Benin-major Canyon, western Niger Delta slope: Marine and Petroleum Geology, v. 24[6], p. 406-433.

Deptuck, M.E., Piper, D.J., Savoye, B., and Gervais, A., 2008, Dimensions and architecture of late Pleistocene submarine lobes off the northern margin of East Corsica: Sedimentology, v. 55[4], p. 869-898.

Deschamps, P., Durand, N., Bard, E., Hamelin, B., Camoin, G., Thomas, A.L., Henderson, G.M., Okuno, J., and Yokoyama, Y., 2012, Ice-sheet collapse and sea-level rise at the Bolling warming 14,600 years ago: Nature, v. 483(7391), p. 559-564.

Doust, H., and Omatsola, E., 1989, Niger delta: American Association of Petroleum Geologists Memoir 48, p. 201-238.

Dykstra, M., and Kneller, B., 2009, Lateral accretion in a deep-marine channel complex: implications for channellized flow processes in turbidity currents: Sedimentology, v. 56[5], p. 1411-1432.

Elliott, T., 2000, Megaflute erosion surfaces and the initiation of turbidite channels: Geology, v. 28[2], p. 119-122.

Evamy, B.D., Haremboure, J., Kamerling, P., Knaap, W.A., Molloy, F.A., and Rowlands, P.H., 1978, Hydrocarbon habitat of Tertiary Niger delta: American Association of Petroleum Geologists Bulletin, v. 62[1], p. 1-39.

Finnegan, N.J., Sklar, L.S., and Fuller, T.K., 2007, Interplay of sediment supply, river incision, and channel morphology revealed by the transient evolution of an experimental bedrock channel: Journal of Geophysical Research: Earth Surface [2003-2012], v. 112[F3].

Finnegan, N.J., and Dietrich, W.E., 2011, Episodic bedrock strath terrace formation due to meander migration and cutoff: Geology, v. 39[2], p. 143-146.

Gervais, A., 2002, Analyse multi-échelles de la morphologie, de la géométrie et de l'architecture d'un système turbiditique sableux profond (système du Golo, marge est-corse, Mer Méditerranée). PhD Thesis, Université Bordeaux 1, Bordeaux, 288 p.

Harvey, A.M., 1991, The influence of sediment supply on the channel morphology of upland streams: Howgill Fells, northwest England: Earth Surface Processes Landforms, v. 16[7], p. 675-684, doi:10.1002/esp.3290160711.

Heiniö, P. and Davies, R.J., 2006, Degradation of compressional fold belts: Deep-water Niger Delta: American Association of Petroleum Geologists Bulletin, v. 90, p. 753-770, doi: 10.1306/11210505090.

Heiniö, P., and Davies, R.J., 2007, Knickpoint migration in submarine channels in response to fold growth, western Niger Delta: Marine and Petroleum Geology, v. 24, p. 434-449, doi: 10.1016/j.marpetgeo.2006.09.002.

Hubbard, S.M., Covault, J.A., Fildani, A., and Romans, B.W., 2014, Sediment transfer and deposition in slope channels: Deciphering the record of enigmatic deep-sea processes from outcrop: Geological Society of America Bulletin, v. 126[5-6], p. 857-871. 
Janocko, M., Cartigny, M.B.J., Nemec, W., and Hansen, E.W.M., 2013a, Turbidity current hydraulics and sediment deposition in erodible sinuous channels: laboratory experiments and numerical simulations: Marine and Petroleum Geology, v. 41, p. 222-249.

Janocko, M., Nemec, W., Henriksen, S., and Warchoł, M., 2013b, The diversity of deep-water sinuous channel belts and slope valley-fill complexes: Marine and Petroleum Geology, v. 41, p. 7-34.

Jegou, I., Savoye, B., Pirmez, C., and Droz, L, 2008, Channel-mouth lobe complex of the recent Amazon Fan: the missing piece: Marine Geology, v. 252, p. 62-77.

Jobe, Z.R., Lowe, D.R., Uchytil, S.J., 2011, Two fundamentally different types of submarine canyons along the continental margin of Equatorial Guinea: Marine and Petroleum Geology, v. 28[3], p. 843-860, doi:10.1016/j.marpetgeo.2010.07.012

Kane, I.A., Kneller, B.C., Dykstra, M., Kassem, A., McCaffrey, W.D., 2007, Anatomy of a submarine channel-levee: an example from Upper Cretaceous slope sediments, Rosario Formation, Baja California, Mexico: Marine and Petroleum Geology, v. 24, p. 540-563. doi:10.1016/j.marpetgeo.2007.01.003.

Kane, I.A., McCaffrey, W.D., and Peakall, J., 2008, Controls of sinuosity evolution within submarine channels: Geology, v. 36[4], p. 287-290.

Kane, I.A., Dykstra, M., Kneller, B.C., Tremblay, S., McCaffrey, W.D., 2009, Architecture of a coarse grained channel-levee system: the Rosario Formation, Baja California, Mexico: Sedimentology, v. 56, p. 2207-2234.

Kane, I.A., and Hodgson, D.M., 2011, Sedimentological criteria to differentiate submarine channel levee subenvironments: exhumed examples from the Rosario Fm. (Upper Cretaceous) of Baja California, Mexico, and the Fort Brown Fm. (Permian), Karoo basin, S. Africa: Marine and Petroleum Geology, v. 28[3], p. 807-823.

Keevil, G. M., Peakall, J., Best, J. L., and Amos, K. J., 2006, Flow structure in sinuous submarine channels: Velocity and turbulence structure of an experimental submarine channel: Marine Geology, v. 229[3], p. 241-257.

Kenyon, N.H., Amir, A. and Cramp, A., 1995, Geometry of the younger sediment bodies of the Indus Fan: in Pickering, K.T., Hiscott, R.N., Kenyon, N.H., Ricci-Lucchi, F., and Smith, R.D.A., eds., Atlas of Deep Environments: Architectural Styles in Turbidite Systems. Chapman and Hall, London, p. 89-93.

Kolla, V., Bandyopadhyay, A., Gupta, P., Mukherjee, B., and Ramana, D.V., 2012, Morphology and internal structure of a recent upper Bengal fan-valley complex: in Prather, B.E., Deptuck, M.E., Mohrig, D., van Hoorn, B., and Wynn, R., eds., Application of the Principles of Seismic Geomorphology to Continental-Slope and Base-of-Slope Systems: Case Studies from Seafloor and Near-Seafloor Analogues: Society for Sedimentary Geology (SEPM) Special Publication 99, p. 347-369.

Konsoer, K., Zinger, J., and Parker, G., 2013, Bankfull hydraulic geometry of submarine channels created by turbidity currents: relations between bankfull channel characteristics and formative flow discharge: Journal of Geophysical Research: Earth Surface, v. 118[1], p. 216-228.

Leopold, L.B., and Maddock, T.Jr., 1953, The hydraulic geometry of stream channels and some physiographic implications: U.S. Geological Survey Professional Paper 252, 56 p.

Lisiecki, L.E., and Raymo, M.E., 2005, A Pliocene-Pleistocene stack of 57 globally distributed benthic $\delta 180$ records: Paleoceanography, v. 20.1., PA1003, doi:10.1029/2004PA001071 
Massong, T.M., and Montgomery, D.R., 2000, Influence of sediment supply, lithology, and wood debris on the distribution of bedrock and alluvial channels: Geological Society of America Bulletin, v. 112[4], p. 591-599.

McHargue, T.R., 1991, Seismic facies, processes, and evolution of Miocene inner fan channels, Indus submarine fan: in Weimer, P. and Link, M.H., eds., Seismic facies and sedimentary processes of submarine fans and turbidite systems, New York Springer, p. 403-413.

McHargue, T., Pyrcz, M.J., Sullivan, M.D., Clark, J.D., Fildani, A., Romans, B.W., Covault, J.A., Levy, M., Posamentier, H.W., and Drinkwater, N.J., 2011, Architecture of turbidite channel systems on the continental slope: patterns and predictions: Marine and Petroleum Geology, v. 28[3], p. 728-743.

Mulder, T., and Syvitski, J.P., 1995, Turbidity currents generated at river mouths during exceptional discharges to the world oceans: The Journal of Geology, v. 103, p. 285-299.

Normark, W.R., and Carlson, P.R., 2003, Giant submarine canyons: Is size any clue to their importance in the rock record?, in Chan, M.A., Archer, A.W., eds., Extreme Depositional Environments: Mega End Members in Geologic Time: Boulder, Colorado. Geological Society of America Special Paper 370, p. 175-190.

Parker, G., P. Wilcock, C. Paola, W. E. Dietrich, and J. Pitlick, 2007, Quasiuniversal relations for bankfull hydraulic geometry of single-thread gravel bed rivers: J. Geophys. Res., v. 112, F04005, doi:10.1029/2006JF000549.

Paull, C.K., Ussler, W.III, Caress, D.W., Lundsten, E., Covault, J.A., Maier, K.L., and Augenstein, S., 2010, Origins of large crescent-shaped bedforms within the axial channel of Monterey Canyon, offshore California: Geosphere, v. 6[6], p. 755-774.

Paull, C.K., Caress, D.W., Ussler, W., Lundsten, E., and Meiner-Johnson, M., 2011, Highresolution bathymetry of the axial channels within Monterey and Soquel submarine canyons, offshore central California: Geosphere, v. 7[5], p. 1077-1101.

Peakall, J., Kane, I.A., Masson, D.G., Keevil, G., McCaffrey, W., and Corney, R., 2012, Global (latitudinal) variation in submarine channel sinuosity: Geology, v. 40[1], p. 11-14.

Piper, D.J.W., Hiscott, R.N., and Normark, W.R. (1999), Outcrop-scale facies analysis and latest Quaternary development of Hueneme and Dume submarine fans, offshore California: Sedimentology, v. 46, p. 47-78.

Pirmez, C., Hiscott, R.N., and Kronen, J.D., 1997, Sandy turbidite successions at the base of channel-levee systems of the Amazon Fan revealed by FMS logs and cores: unraveling the facies architecture of large submarine fans: in Proceedings of the Ocean Drilling Program, Scientific results, v. 155, p. 7-33.

Pirmez, C., Beaubouef, R.T., Friedmann, S.J., and Mohrig, D.C., 2000, Equilibrium profile and base level in submarine channels: examples from Late Pleistocene systems and implications for the architecture of deepwater reservoirs: in Gulf Coast Section SEPM Foundation 20th Annual Bob F. Perkins Research Conference, Global Deep-Water Reservoirs, p. 782-805.

Pirmez, C., and Imran, J., 2003, Reconstruction of turbidity currents in Amazon Channel: Marine and Petroleum Geology, v. 20[6], p. 823-849.

Prather, B.E., Pirmez, C., Sylvester, Z., and Prather, D.S., 2012, Stratigraphic response to evolving geomorphology in a submarine apron perched on the upper Niger Delta slope: in Prather, B.E., Deptuck, M.E., Mohrig, D., van Hoorn, B., and Wynn, R., eds., Application of the Principles of Seismic Geomorphology to Continental-Slope and Baseof-Slope Systems: Case Studies from Seafloor and Near-Seafloor Analogues: Society for 
Sedimentary Geology (SEPM) Special Publication 99, p. 347-369.

Reading, H.G., and Richards, M., 1994, Turbidite systems in deep-water basin margins classified by grain size and feeder system: American Association of Petroleum Geologists Bulletin, v. 78[5], p. 792-822.

Romans, B.W., Normark, W.R., McGann, M.M., Covault, J.A., and Graham, S.A., 2009, Coarsegrained sediment delivery and distribution in the Holocene Santa Monica Basin, California: Implications for evaluating source-to-sink flux at millennial time scales: Geological Society of America Bulletin, v. 121[9-10], p. 1394-1408.

Sawyer, D.E., Flemings, P.B., Shipp, R.C., and Winker, C.D., 2007, Seismic geomorphology, lithology, and evolution of the late Pleistocene Mars-Ursa turbidite region, Mississippi Canyon area, northern Gulf of Mexico: American Association of Petroleum Geologists Bulletin, v. 91[2], p. 215-234, doi:10.1306/08290605190

Smith, D.P., Kvitek, R., Iampietro, P.J., and Wong, K., 2007, Twenty-nine months of geomorphic change in upper Monterey Canyon (2002-2005): Marine Geology, v. 236[1], p. 79-94.

Straub, K.M., Mohrig, D., McElroy, B., Buttles, J., and Pirmez, C., 2008, Interactions between turbidity currents and topography in aggrading sinuous submarine channels: A laboratory study: Geological Society of America Bulletin, v. 120[3-4], p. 368-385.

Stuiver, M., and Polach, H.A., 1977, Discussion; reporting of C-14 data: Radiocarbon, v. 19[3], p. 355-363.

Stuiver, M., Reimer, P.J., and Reimer, R.W., 2005, CALIB 7.0. http://calib.qub.ac.uk/calib/

Sylvester, Z., Pirmez, C., and Cantelli, A., 2011, A model of submarine channel-levee evolution based on channel trajectories: Implications for stratigraphic architecture: Marine and Petroleum Geology, v. 28[3], p. 716-727.

Sylvester, Z., Deptuck, M.E., Prather, B.E., Pirmez, C., and O’Byrne, C., 2012, Seismic stratigraphy of a shelf-edge delta and linked submarine channels in the North-Eastern Gulf of Mexico, in Prather, B.E., Deptuck, M.E., Mohrig, D., van Hoorn, B., and Wynn, R., eds., Application of the Principles of Seismic Geomorphology to Continental-Slope and Base-of-Slope Systems: Case Studies from Seafloor and Near-Seafloor Analogues: Society for Sedimentary Geology (SEPM) Special Publication 99, p. 31-59.

Sylvester, Z., Pirmez, C., Cantelli, A., and Jobe, Z.R., 2013, Global (latitudinal) variation in submarine channel sinuosity: Comment: Geology, v. 41[5], p. e287-e287.

Yang, S.L., Belkin, I.M., Belkina, A.I., Zhao, Q.Y., Zhu, J., and Ding, P.X., 2003, Delta response to decline in sediment supply from the Yangtze River: evidence of the recent four decades and expectations for the next half-century: Estuarine, Coastal and Shelf Science, v. 57[4], p. 689-699. 
Figure 1. Overview map of the Niger Delta, showing the location of 3D seismic reflection data coverage. The study area is approximately $120 \mathrm{~km}$ offshore and in 1,100 m water depth. Also shown are seafloor images from Deptuck et al. (2007) and Heinio and Davies (2007). Background image courtesy of Google Earth and the Global Multi Resolution Topography overlay.

Figure 2. Seafloor dip-magnitude map (colors) draped on the seafloor bathymetry (contours with contour interval $100 \mathrm{~m}$ ). Note the three channel systems traversing the slope from northeast to southwest and the perpendicular shale ridge and diapir province. For location, see Figure 1.

Figure 3. Seafloor amplitude (colors) draped on the seafloor bathymetry (contours with contour interval $10 \mathrm{~m}$ ) and the 24 piston core locations. A) Map showing the tributaries to the channel system and all core locations. Black boxes denote the location of Parts B, C, and D. B) Detailed map of the channel system, with channel margin slides (Sl) and meander cutoff terraces (Co) labeled. Note the low-amplitude and discontinuous, pockmarked thalweg of the $\mathrm{Y}$ channel upstream of the $\mathrm{Y}^{\prime}$ junction, indicating abandonment. The $\mathrm{Y}^{\prime}$ channel empties into the $\mathrm{Y}$ channel, and is currently the source of sediment for the study area. Red polygon denotes the location of the AUV multibeam bathymetry and chirp profile data shown in Figure 4. C, D) show detailed maps of the seafloor amplitudes associated with the channel system and core locations. Note the high amplitudes in the channel thalweg, but also on inner levees/terraces (e.g., near cores g1, g19, and g16/g22).

Figure 4. High-resolution multibeam bathymetry (contour interval $2 \mathrm{~m}$ ) and piston-core locations. For location, see Figure 3B.

Figure 5. Seismic cross section (location shown in Fig. 3B) denoting the previous channel systems and the phases of evolution of the $\mathrm{Y}$ channel system. Rotated channel-margin slides result in the vertical stacking of successive channel deposits; black dashed line shows a marker horizon where up to $150 \mathrm{~m}$ of offset is observed. Note the narrowing of the channel through the successive phases and the meander cutoff present in Phase 2 deposits.

Figure 6. Series of maps showing the evolutionary phases of the Y channel system. The modern channel centerline is overlaid on each image.

A. Top Phase 1 channel form, a wide, low sinuosity channel form influenced by large rotated channel-margin slides. Due to partial postdepositional erosion by Phase 2, the overbank areas of this channel form cannot be fully mapped.

B. Phase 2 thickness map (draped on the Top Phase 1 channel form). Note that Phase 2 deposits are thin near the mapped channel form (pink line) and in cutoff locations, indicating reincision during Phase 2.

C. Top Phase 2 channel form. Phase 2 was characterized by high-sinuosity channel forms and numerous meander cutoffs. The arcuate terraces on the channel margins indicate the location of meander cutoffs.

D. Phase 3 thickness (draped on the Top Phase 2 channel form). The thickest deposits of Phase 3 are on the outer banks of the channel, indicating preferential deposition on the outer banks. inside the channel, but in asymmetric fashion: thin on the inner bends and thick on the outer bends.

E. Top Phase 3 channel form. Outer-bank deposition during Phase 3 caused a reduction in sinuosity, shown by the difference in the Top Phase 2 centerline (link line) and the Top Phase 3 centerline (black line).

F. Phase 4 thickness (draped on the Top Phase 3 channel form), showing deposition of inner levees on the margins of the $Y$ channel during Phase 4 . The growth of the inner levees preferentially occurs on the outer bends of the channel, causing further narrowing and straightening of the channel. 
G. Top Phase 4 (seafloor) channel form. Overlaid are Phase 2, 3, and 4 centerlines, demonstrating the planform evolution of channel morphology. Note the progressive straightening of the channel from Phase 2 to Phase 4.

Figure 7. Evolution of the $\mathrm{Y}$ channel system (location of cross section shown in Fig. 3B). Lateral migration and degradation during Phase 1 forms a large lateral-migration package (dashed lines show migration). Phase 2 creates a high-sinuosity, aggradational channel form with numerous cutoffs. Abandonment of the $\mathrm{Y}$ feeder channel during Phase 3 results in narrowing and straightening of the channel through outer-bank deposition of muddy, lowamplitude, draping facies. Reoccupation during Phase 4 results in inner-levee deposition and further narrowing and straightening of the channel.

Figure 8. Phase 2 planform channel evolution. A) Horizon slice from Phase 2 with co-rendered RMS amplitude and discontinuity (i.e., semblance) volumes. Note the numerous meander cutoffs with high-amplitude (i.e., sandy) fill. B) The meander cutoffs form arcuate terraces adjacent to the Top Phase 2 channel form. These terraces still influence the modern seafloor and are sites of enhanced deposition during Phases 3-4.

Figure 9. Evolution of Phase 3 channel fill. A) Phase 3 thickness map (colors) draped on the Top Phase 2 surface (10 $\mathrm{m}$ contour interval). Outer-bend thicks and the inner-bank thins act to straighten the channel planform during Phase 3 (compare pink and black lines). Phase 2 meander cutoffs shown in gray. Red lines show location of cross sections B, C, and D. B-D) Cross sections through an entire Phase 3 channel bend that show the lower channel fill dipping from inner to outer bank, and the upper channel fill dipping from outer to inner bank. Lower channel fill is likely lateral migration deposits, and the upper channel fill is the abandonment fill that is "plastered" against the outer bank, decreasing the sinuosity of the channel-form during Phase 3. Note the location of the meander cutoffs responsible for the formation of the arcuate terraces in Part A.

Figure 10. Seismic line (top) and chirp sub bottom profile (bottom) at the same scale. This straight reach of the Y channel has experienced equal inner-levee growth on both margins during Phase 4, resulting in a pronounced reduction in channel width. Note also the low-amplitude abandonment fill during Phase 3.

Figure 11. Characterization of the $Y$ channel at core locations g19-21. A) 3D seismic profile showing the phases of evolution of the $\mathrm{Y}$ channel - note the progressive narrowing during Phases 3 and 4 . The inner levee is better developed on the south side of the channel, perhaps due to slight curvature of the modern channel planform. Inset shows line location and seafloor amplitude. B) Chirp sub-bottom profile demonstrating the architecture and lithologic composition of the Phase 4 inner levees. Age control indicates that the growth of the Phase 4 inner levee began at $\sim 45 \mathrm{ka}$. The g21 oxygen isotope age record (red line) matched with the LR04 benthic stack (black line) allows the estimation of the Top Phase 2 channel form to $\sim 130 \mathrm{ka}$. Note the variable thickness of the Holocene hemipelagic drape, suggesting modern channel activity. C) 1x vertical exaggeration line trace of the chirp line in Part B, demonstrating the bed thinning and pinchout with increasing distance away from the channel. D) Core correlation panel, showing the decrease in bed thickness, sand content, and sedimentation rate away from the channel thalweg.

Figure 12. Chirp sub-bottom profile across a relatively straight reach of the $Y$ channel. Note the narrowing of the channel by inner-levee deposition during Phase 4. Cores g7, g9, and g10 (inset at right) demonstrate the decrease in bed thickness and sand content with increasing distance from the channel thalweg. Radiocarbon ages indicate that Phase 4 began $\sim 53 \mathrm{ka}$, and was abandoned at $19 \mathrm{ka}$.

Figure 13. Chirp sub-bottom profile across a tight meander bend. Cores g22 and g17 are shown on the cross section to scale. Phase 4 deposits consist of thin-bedded inner-levee deposits that are thicker on the outer bend (cored by g22), and thick-bedded channel fill. Inset shows correlation of the two cores using lithology and radiocarbon age 
dating. Note the contrast in bed thickness and sand content between the inner levee (g22) and the channel thalweg (g17).

Figure 14. Thickness patterns of Phase 4 deposits as mapped by chirp profiles. A) Thickness map of the lower, sand-rich Phase 4 deposits, with thicks (pinks) occurring on the outer banks of the channel. B) Thickness map of the upper, mud-rich Phase 4 deposits, showing a pattern similar to Part A, suggesting that muddy flows are currently building inner-levee deposits on the outer banks of the Y channel.

Figure 15. Cross section demonstrating the $\mathrm{Y}^{\prime}$ feeder channel and the active and inactive segments of the $\mathrm{Y}$ channel. For location, see Figure 2B. From left to right are: the active $\mathrm{Y}$ channel, the $\mathrm{Y}^{\prime}$ feeder channel, and the abandoned $\mathrm{Y}$ channel. Note the difference in channel width and shape and also the contrast in amplitude between the active and abandoned segments of the $\mathrm{Y}$ channel. The incision of the $\mathrm{Y}^{\prime}$ channel and the increase in amplitude at the beginning of Phase 4 (green line) demonstrates the renewed influx of sand into the $\mathrm{Y}$ channel system. Phase 4 flows sourced from the $\mathrm{Y}^{\prime}$ channel are narrowing the $\mathrm{Y}$ channel by the deposition of inner levees.

Figure 16. Overview of the $\mathrm{Y}^{\prime}$ feeder channel and associated cores. 3D seismic is of lower resolution than that in the Y channel. A) Map showing the depth contours, amplitudes, and core locations. B, C) Profiles across the $\mathrm{Y}^{\prime}$ channel and through the core locations. The $\mathrm{Y}^{\prime}$ channel was initiated only recently (beginning of Phase 4), as demonstrated by the increase in amplitudes and channelized geometries near the seafloor. The location of the $\mathrm{Y}^{\prime}$ channel seems to be influenced by topography created by an underlying mass-transport deposit. D) Detail of the a1, a3, and a4 cores. Limited penetration prevents dating of channel initiation (i.e. Phase 4), although the end of Phase 4 is $\sim 14.5 \mathrm{ka}$, much later than the $20 \mathrm{ka}$ abandonment in the $\mathrm{Y}$ channel.

Figure 17. Evolution of channel cross sectional area (CSA). A) Cross section (location shown in Fig. 3D) showing the evolution of channel CSA through time. The progressive narrowing of the $\mathrm{Y}$ channel is likely caused by changes in sediment supply. B) Multiple channel cross sections taken perpendicular to the channel during Phases 1-4. A qualitative average of the cross sections is shown as a grey polygon for each phase. The progressive decrease in channel CSA is shown in the inset at right, with Phases 1,2, and 3 having 3.9, 1.8, and 1.5 times, respectively, the area of the modern Y channel (i.e., Top Phase 4 in Fig. 6G).

Figure 18. Plots of age vs. depth derived from radiocarbon analyses. A) All calibrated ages (with 2 sigma error) from the Y (blue) and Y' (black) channels. Core g21 (red line) represents the "background" out-of-channel sedimentation rate. B) Ages $<25 \mathrm{ka}$ in the $\mathrm{Y}$ channel, split into two populations, the sand-rich thalweg and innerlevee deposits (blue) and the muddy, post-abandonment deposits (red). Model II regressions are shown with solid lines. The sands were deposited $4.5 x$ faster than the muds. No sand was deposited in the Y channel system after 18,712 years BP.

Figure 19. Plot of age vs. sedimentation rate for the $Y$ channel system. Inset shows the cumulative frequency distribution of these data. Approximate sea level derived from the LR04 benthic stack (after Lisiecki and Raymo, 2005) is also shown (right-hand axis). Sands recovered from the thalweg and inner levees of the Y channel (blue dots) have very high sedimentation rates, which abruptly end at $19 \mathrm{ka}$. Although poor core recovery (Fig. 15D) prevents full characterization, the sedimentation rate for the sandy interval in the $\mathrm{Y}^{\prime}$ channel (black dot) suggests bypass (also see Fig. 18A). The muddy units in the $\mathrm{Y}$ and $\mathrm{Y}^{\prime}$ channels do not show correlation to sea level, implying that they represent background sedimentation.

Figure 20. Reservoir prediction in the Bonga reservoir, offshore Nigeria. A) Same-scale comparison of the Y channel system and a Bonga reservoir. Inner levees are isolated and volumetrically insignificant (0.5-2 mmbbl). The Bonga 690 reservoir has similar geometries and scaling, indicating that the Bonga out-of-channel deposits are likely to be volumetrically small and may also exhibit poor communication. Image at right courtesy of Ciaran O'Byrne. B) Comparison of core from Bonga and the $\mathrm{Y}$ channel system. In both cores, thin-bedded ripple-laminated sands are 
interbedded with burrowed muds. Note the similarity in bed thickness and stacking pattern. Under compaction to typical reservoir depths, the N/G of the g19 core would increase from $68 \%$ to $80 \%$ due to differential compaction of mud. 


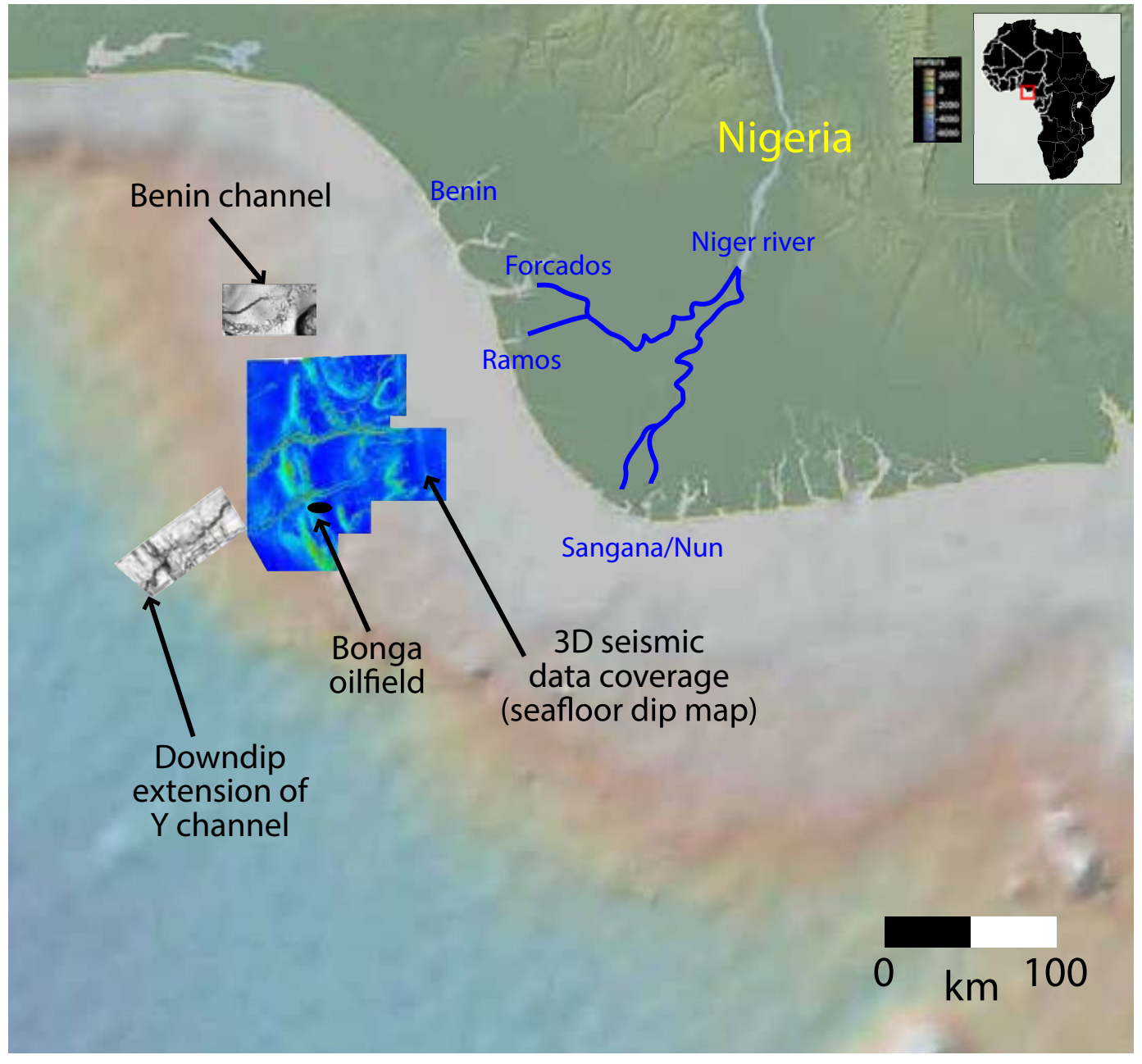




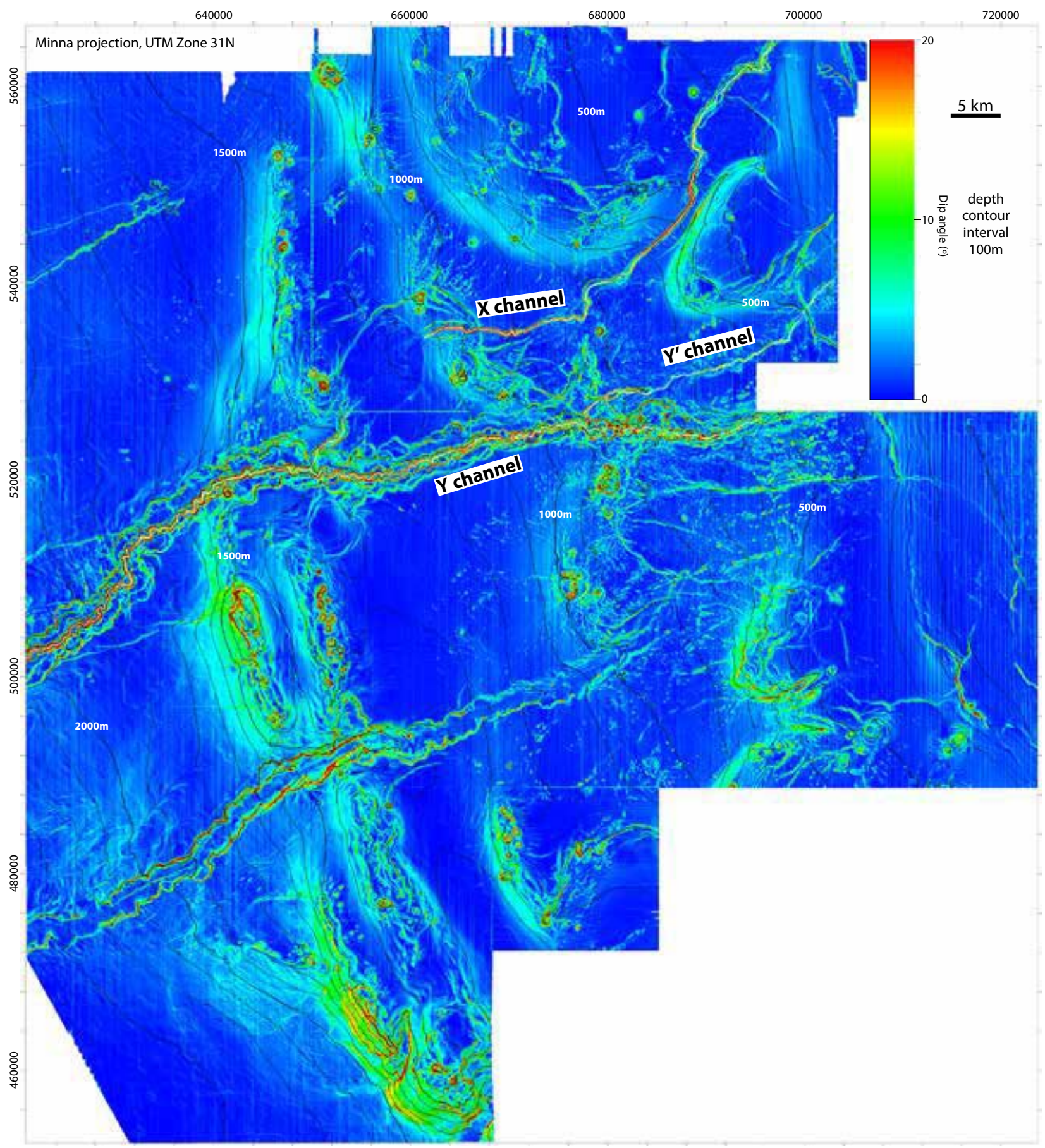




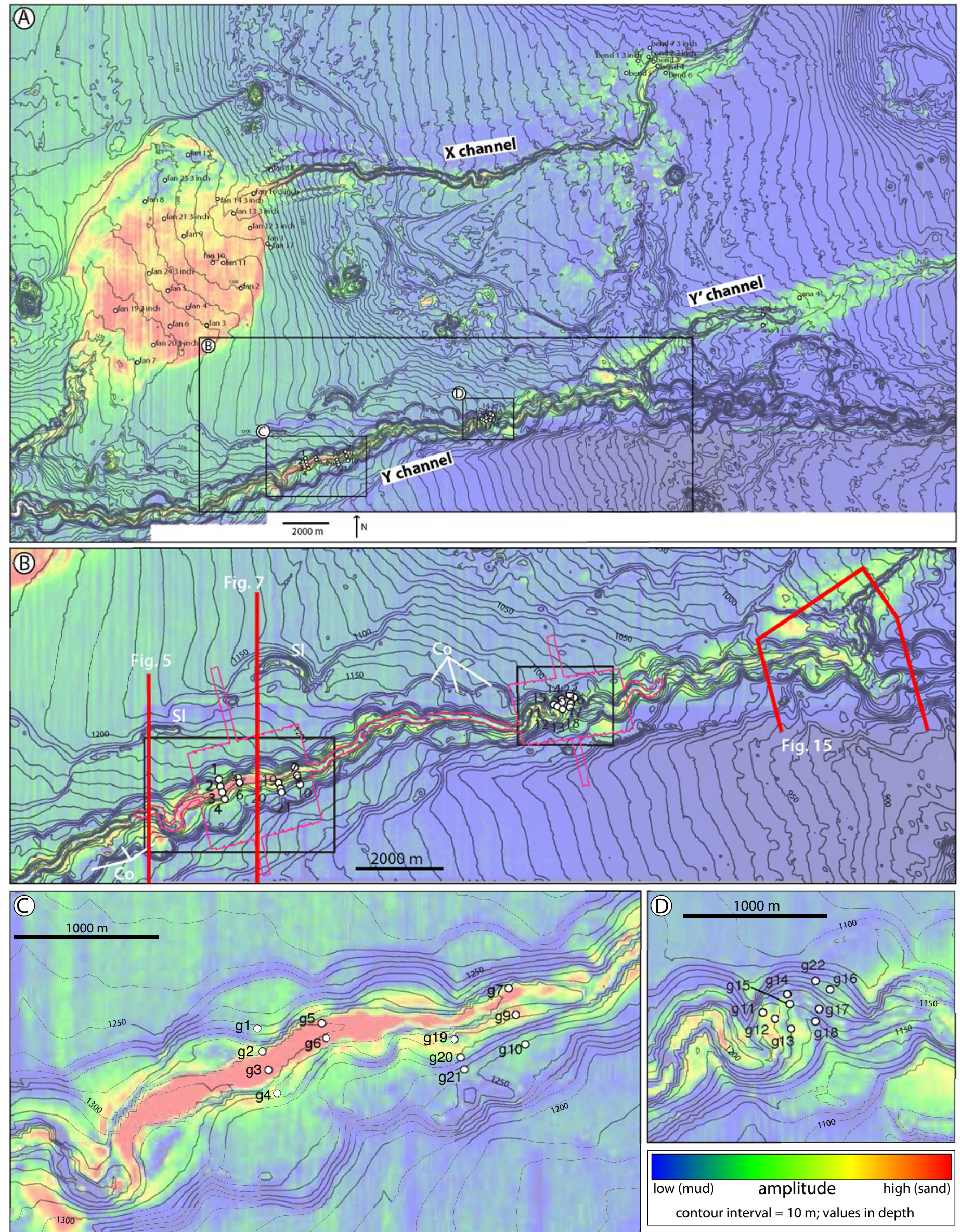



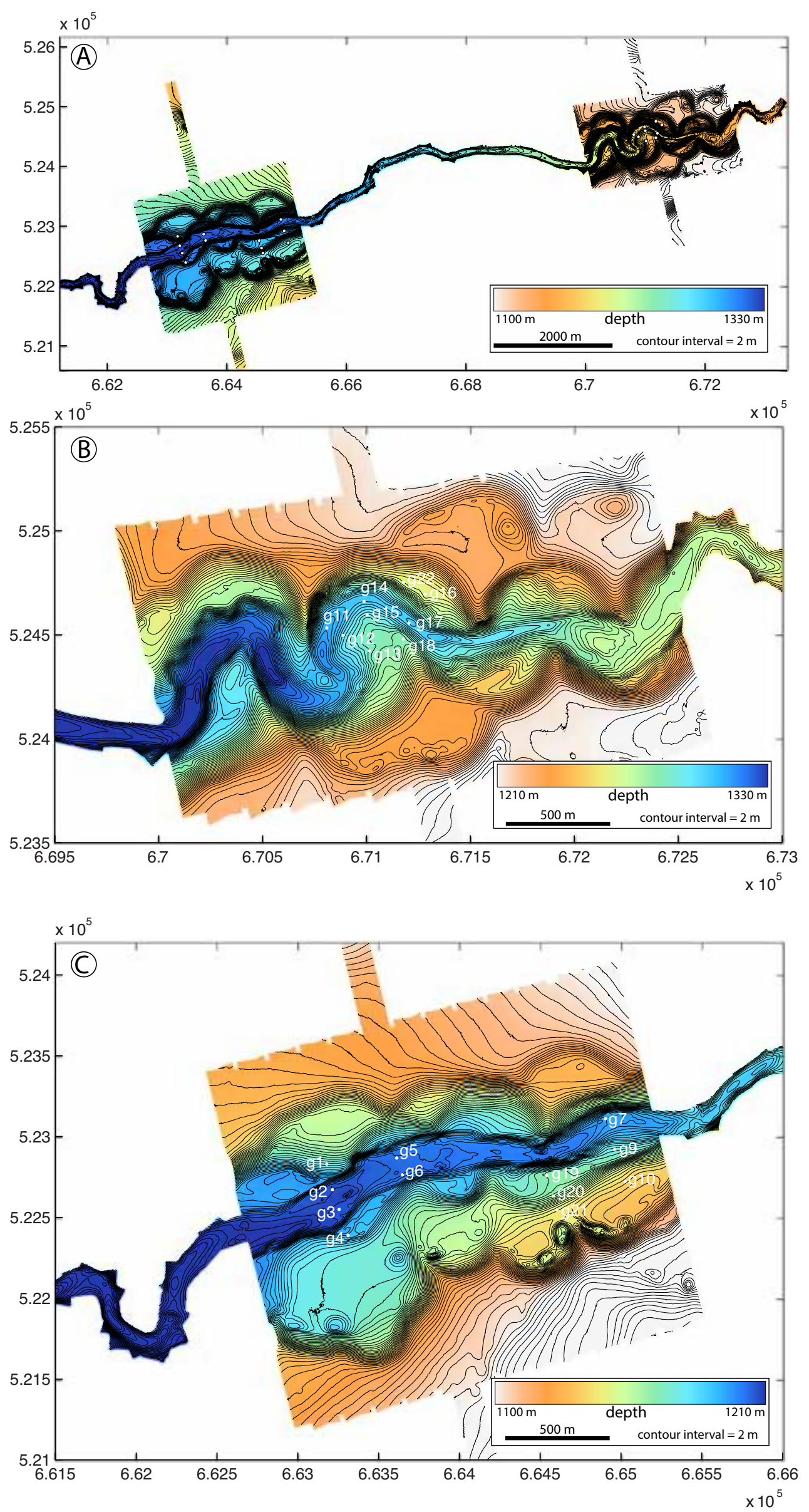


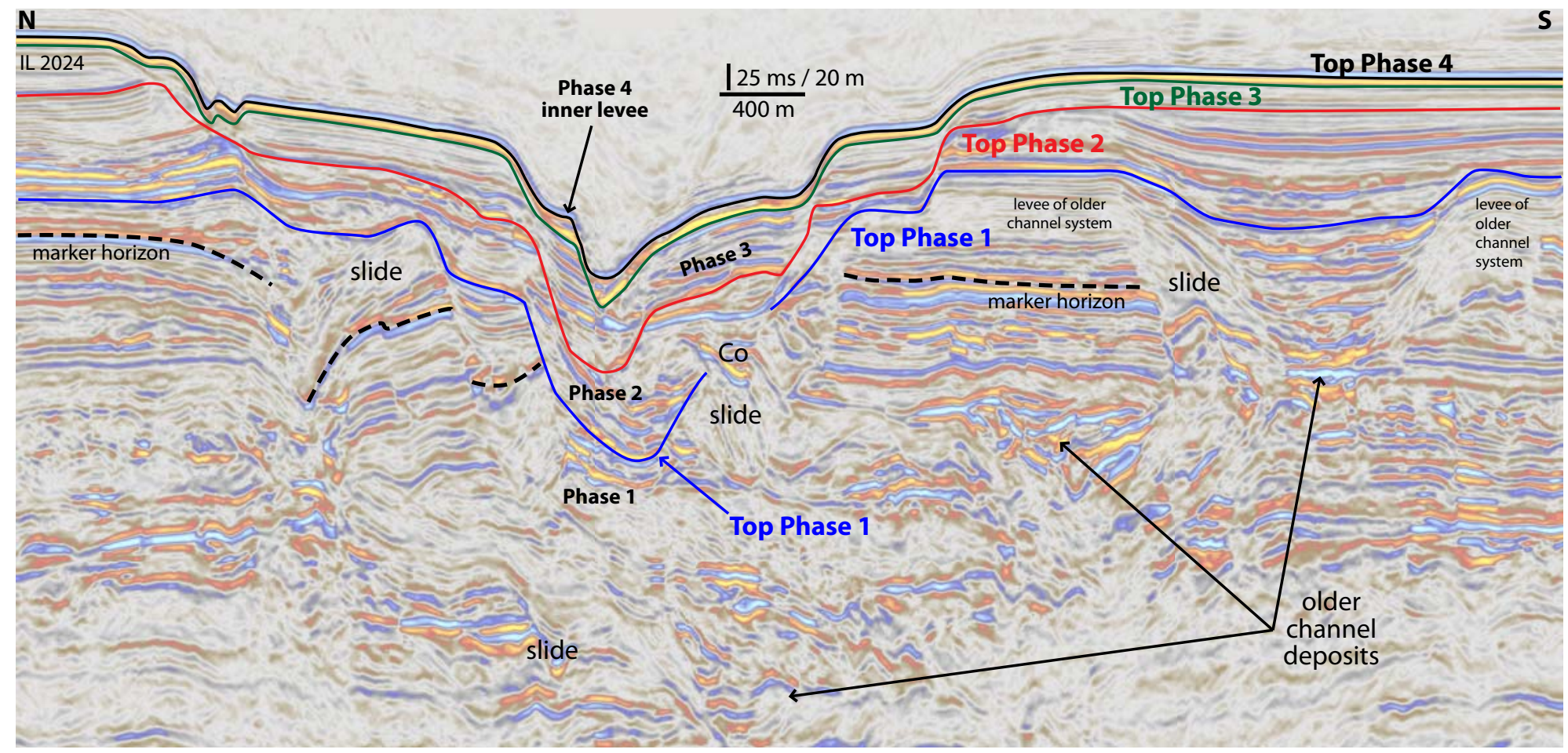



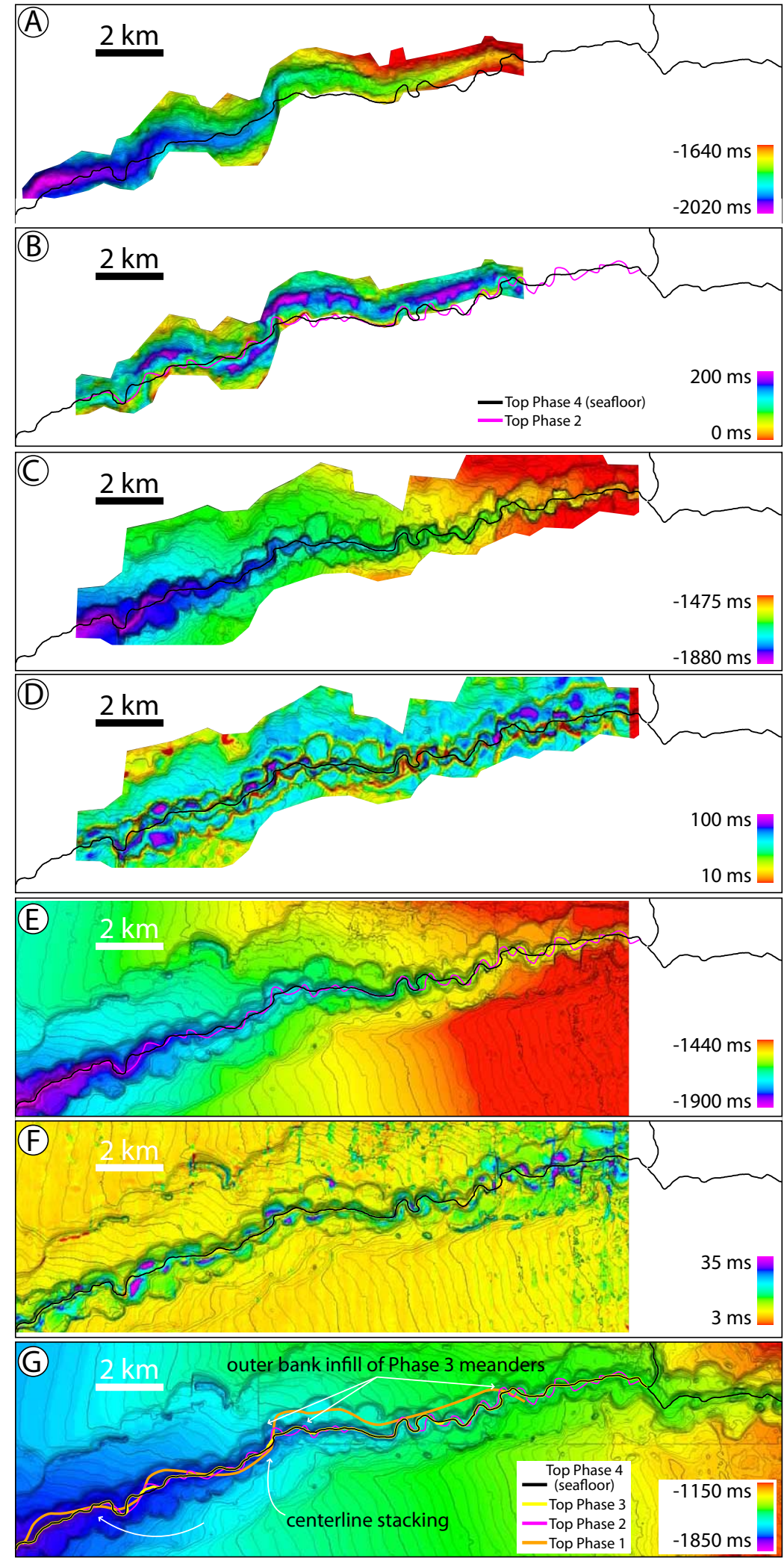

Top Phase 1 channel-form

- 1,000 m width

- low sinuosity (1.1)

Phase 2 time thickness

- thin where cutoffs are present, indicating erosion

\section{Top Phase 2 channel-form}

- 300 m width

- high sinuosity (1.4)

- sets up modern bathymetry

Phase 3 time thickness

- thick in outer bend channel fill

- thick in oxbow terraces

Top Phase 3 channel-form

- $250 \mathrm{~m}$ width (decreased due to inner levee growth)

- sinuosity of 1.22

\section{Phase 4 time thickness}

- thick deposits on inner levees, preferentially on outer bends - thin in the channel thalweg

\section{Top Phase 4 channel-form}

- $200 \mathrm{~m}$ width

- sinuosity of 1.21 (decreased from Phase 3)

- infilling of Phase 3 meanders

- channel margin slides cause centerline stacking 


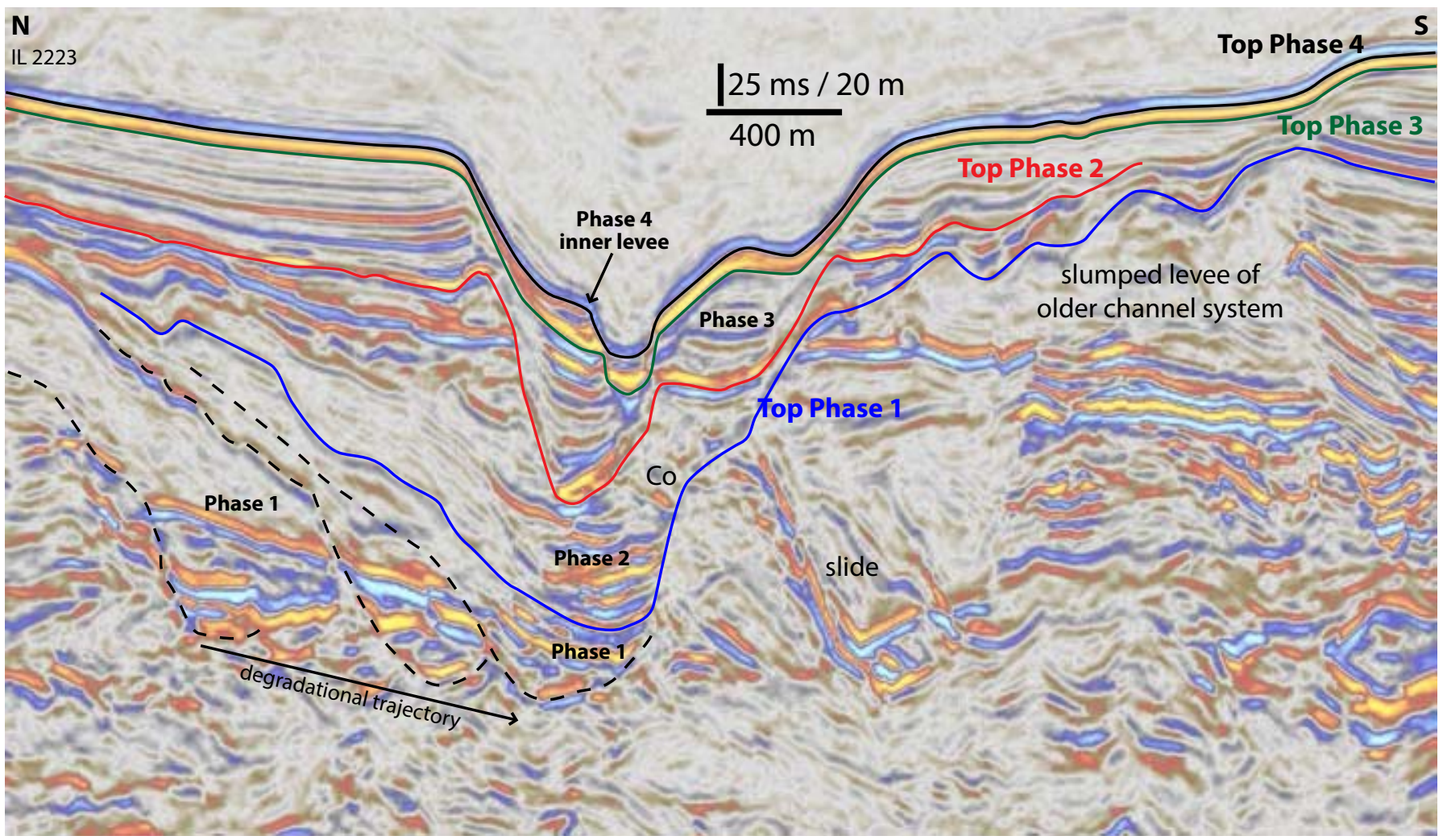



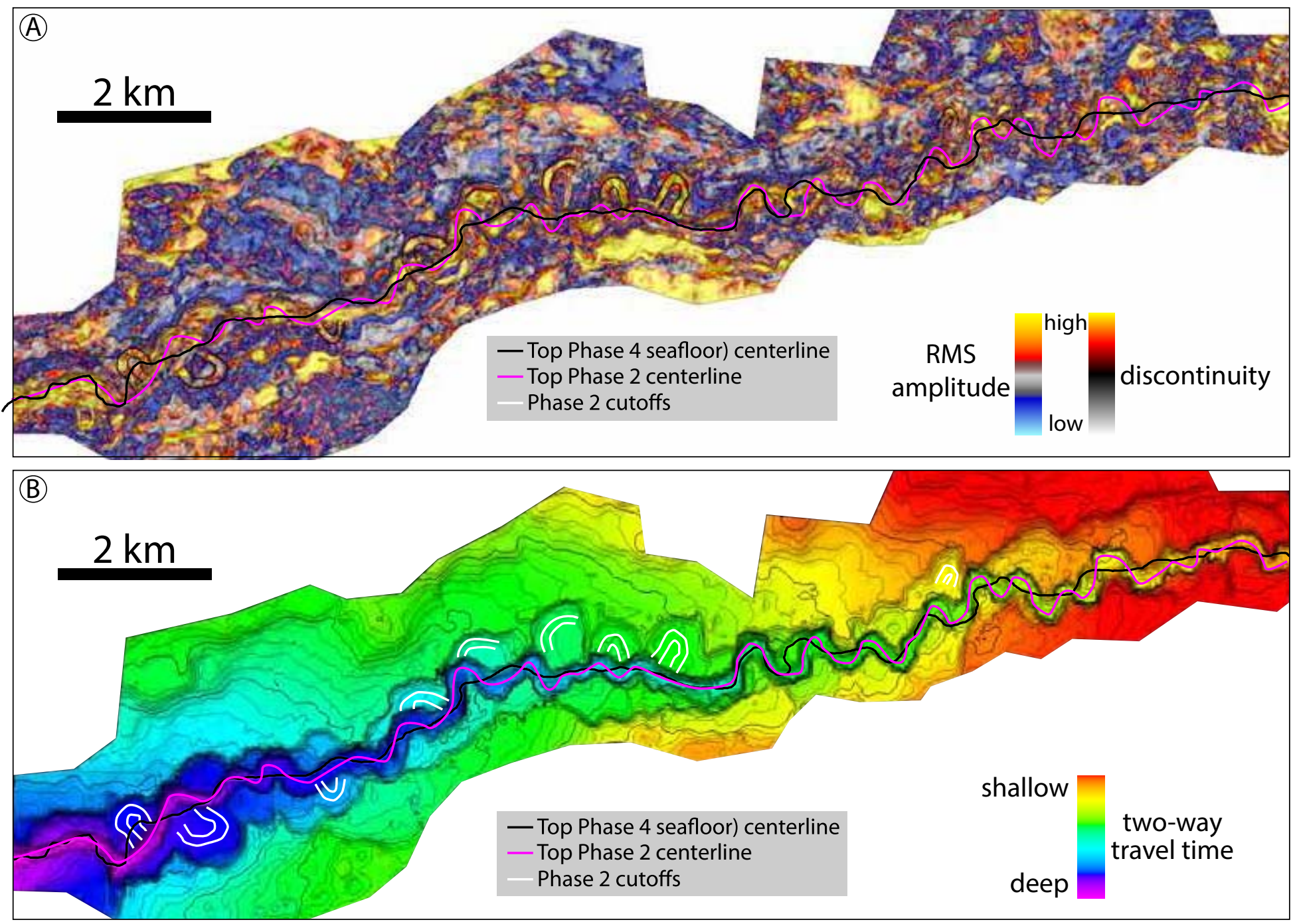

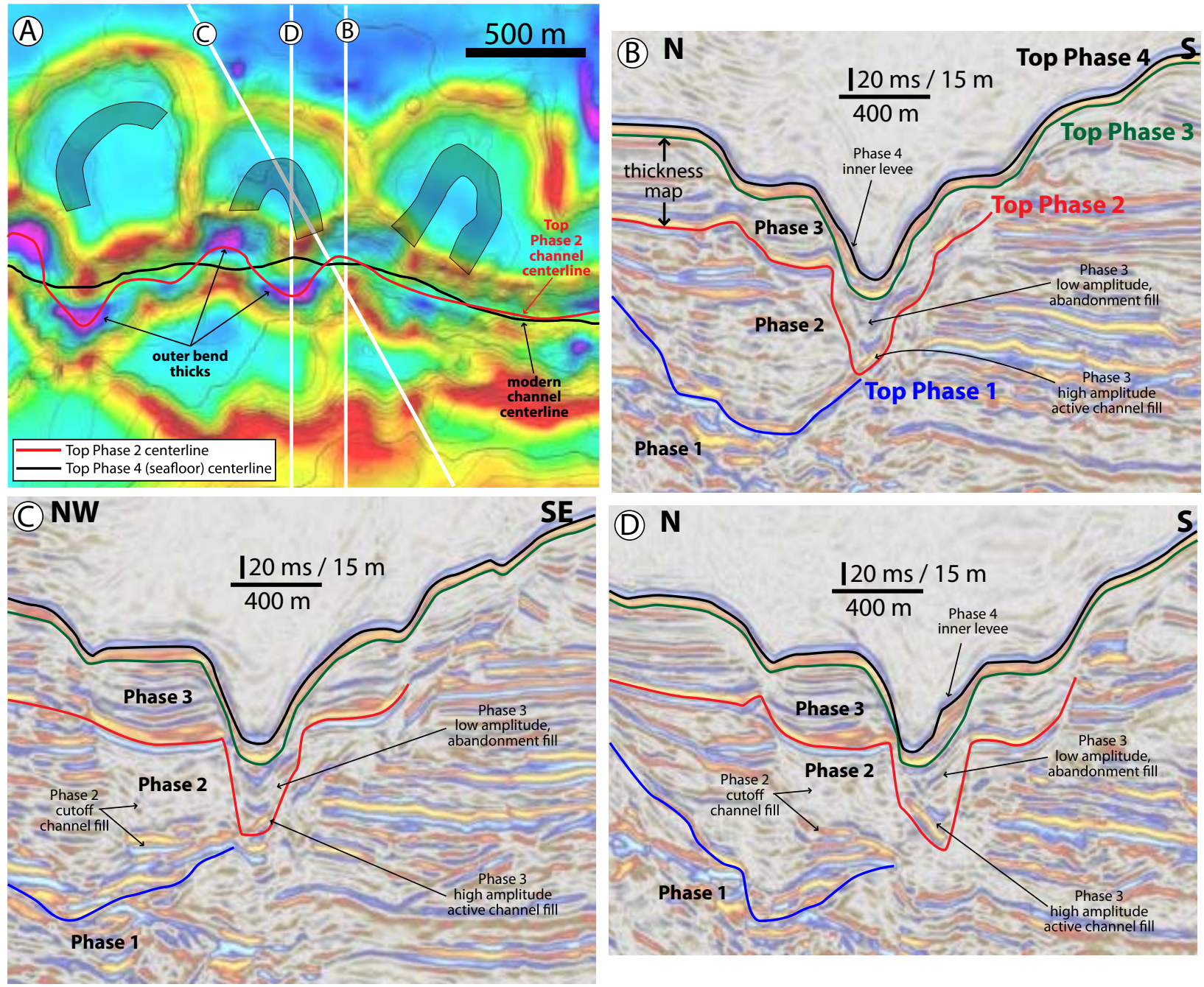

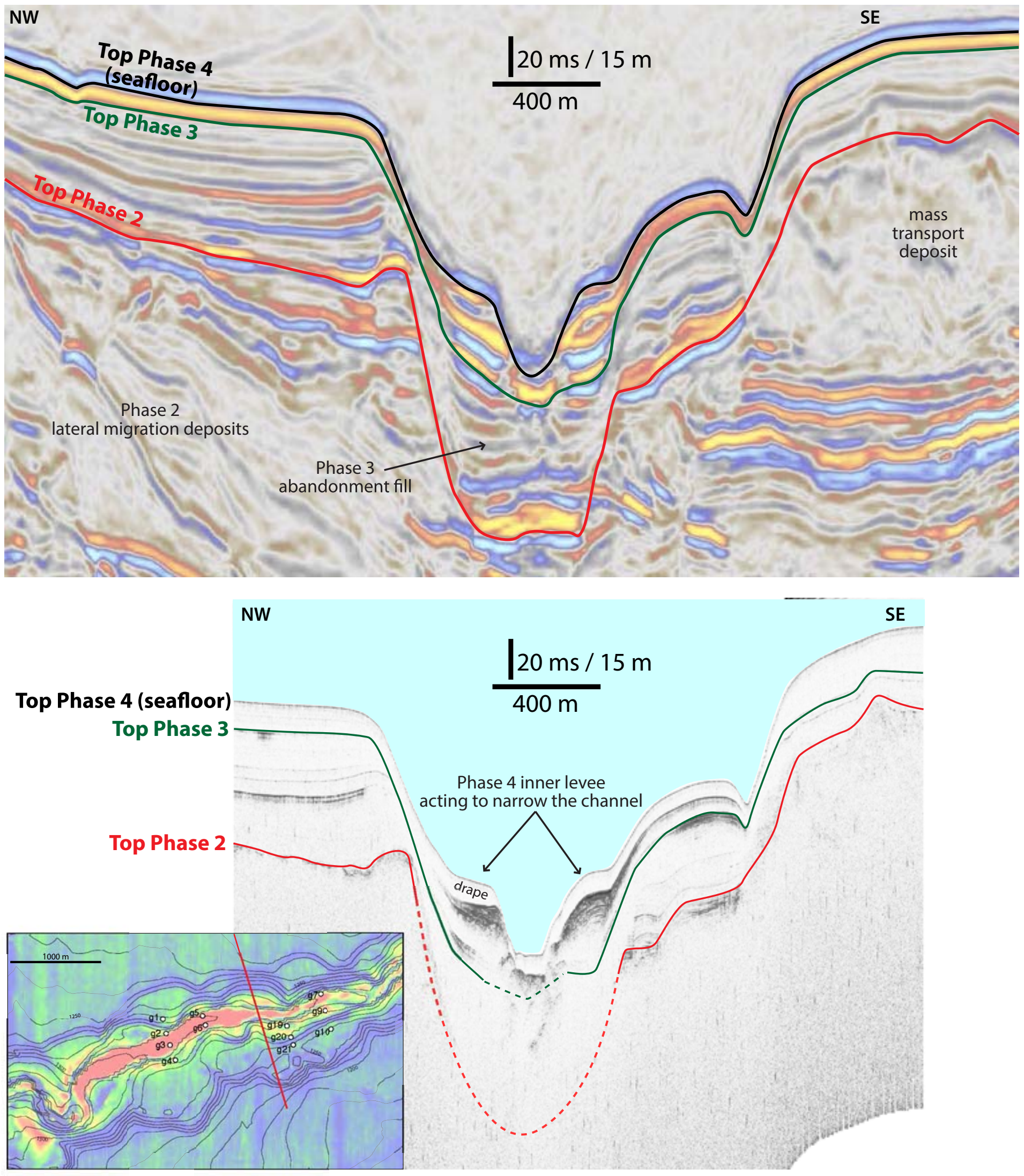

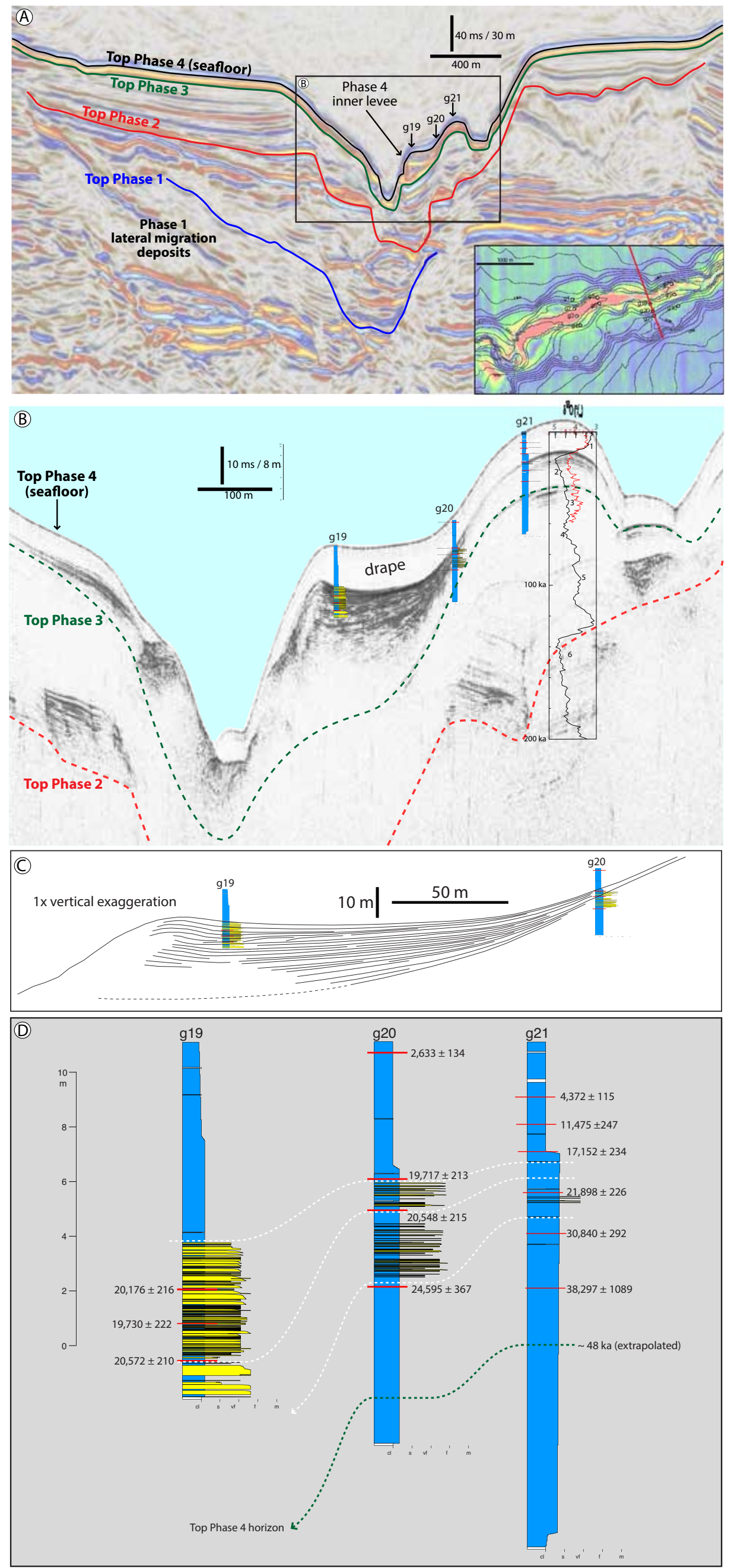


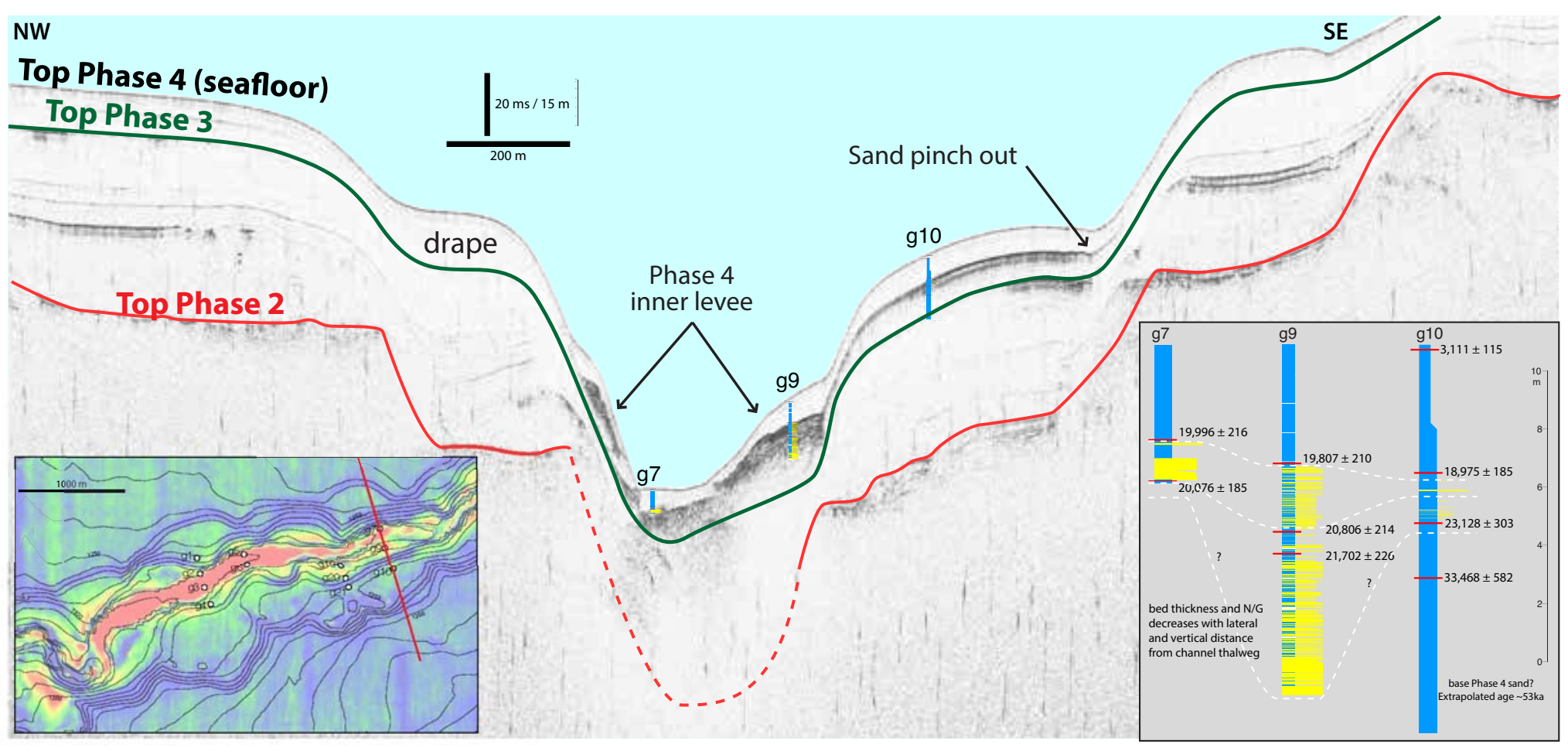




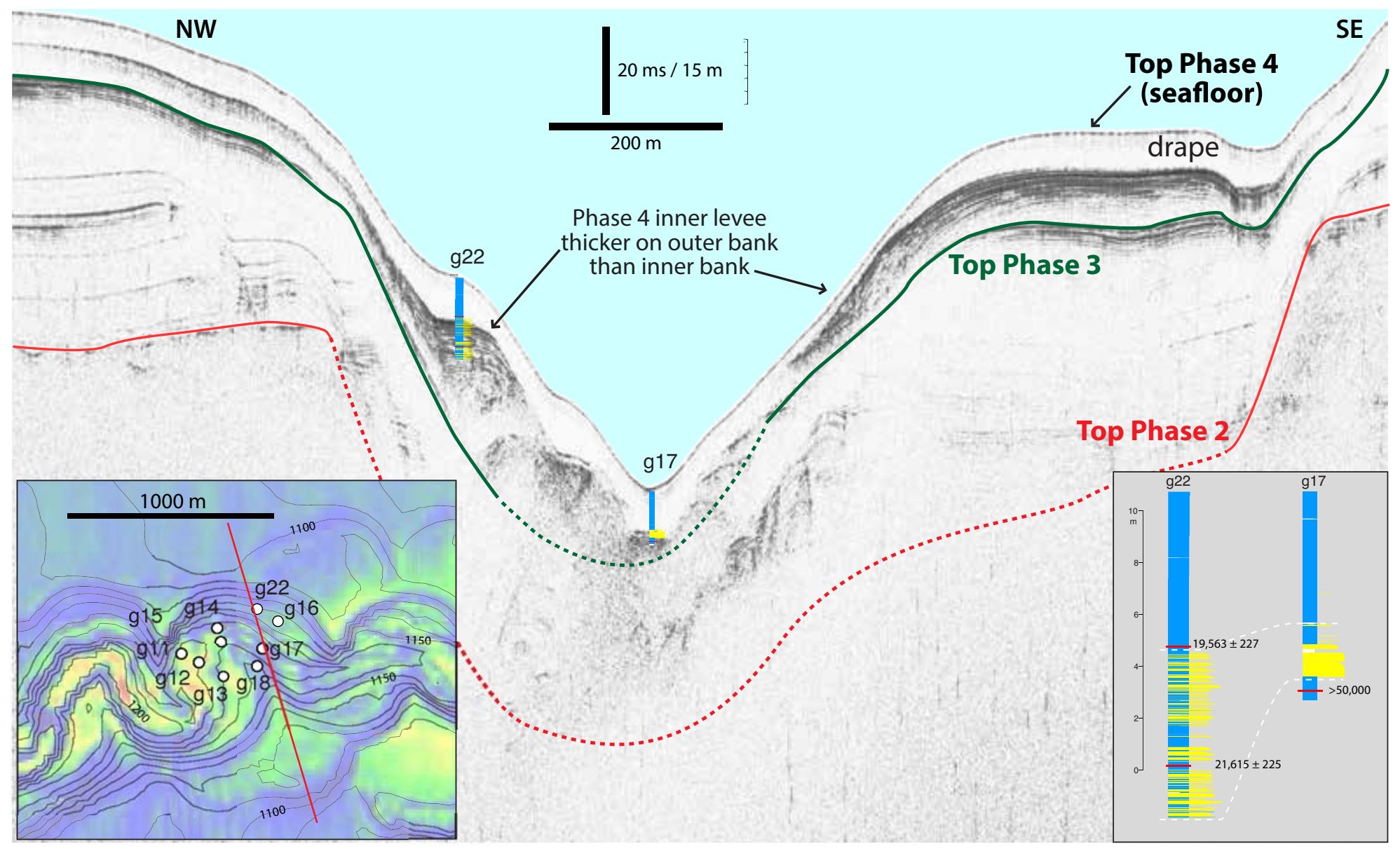



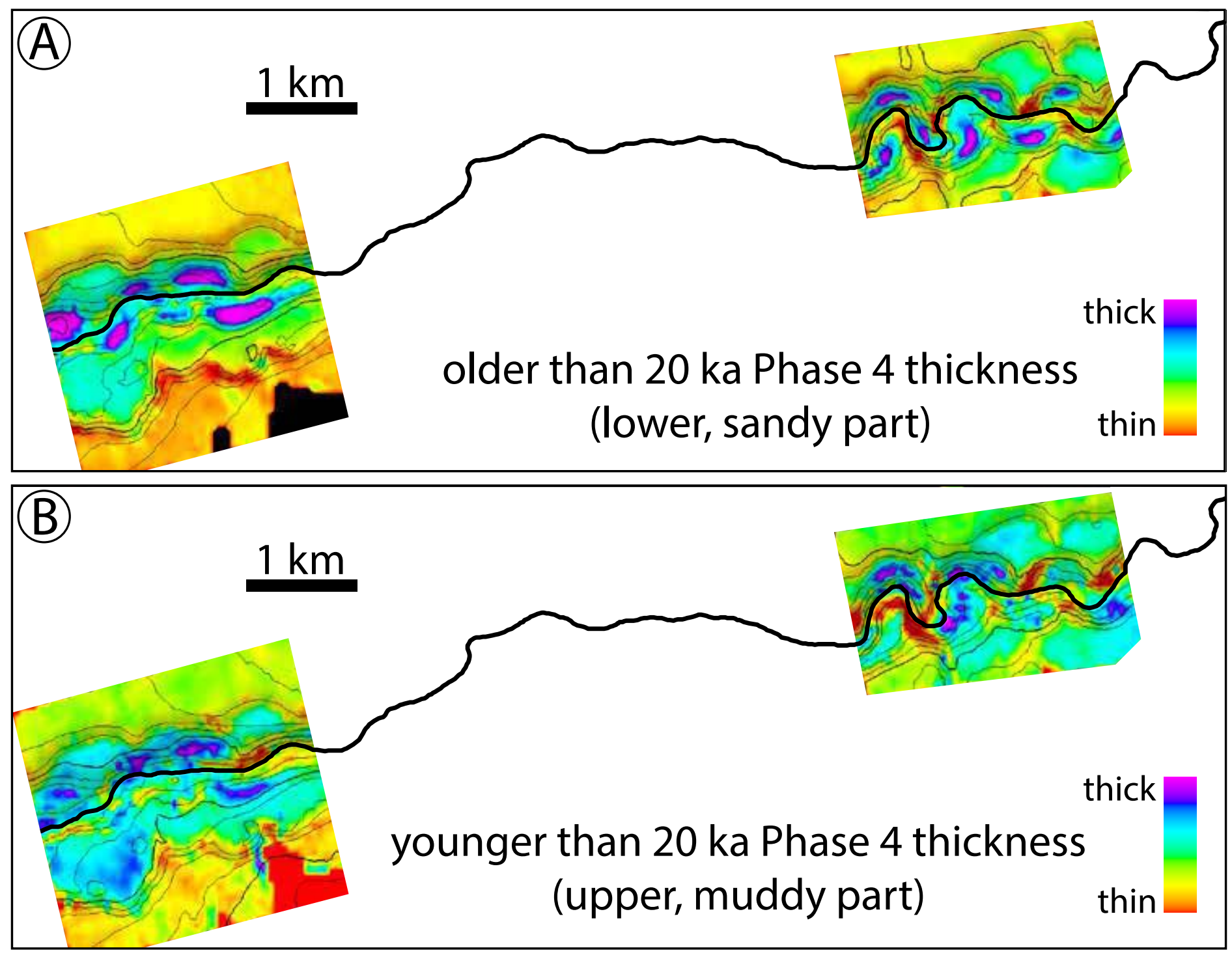


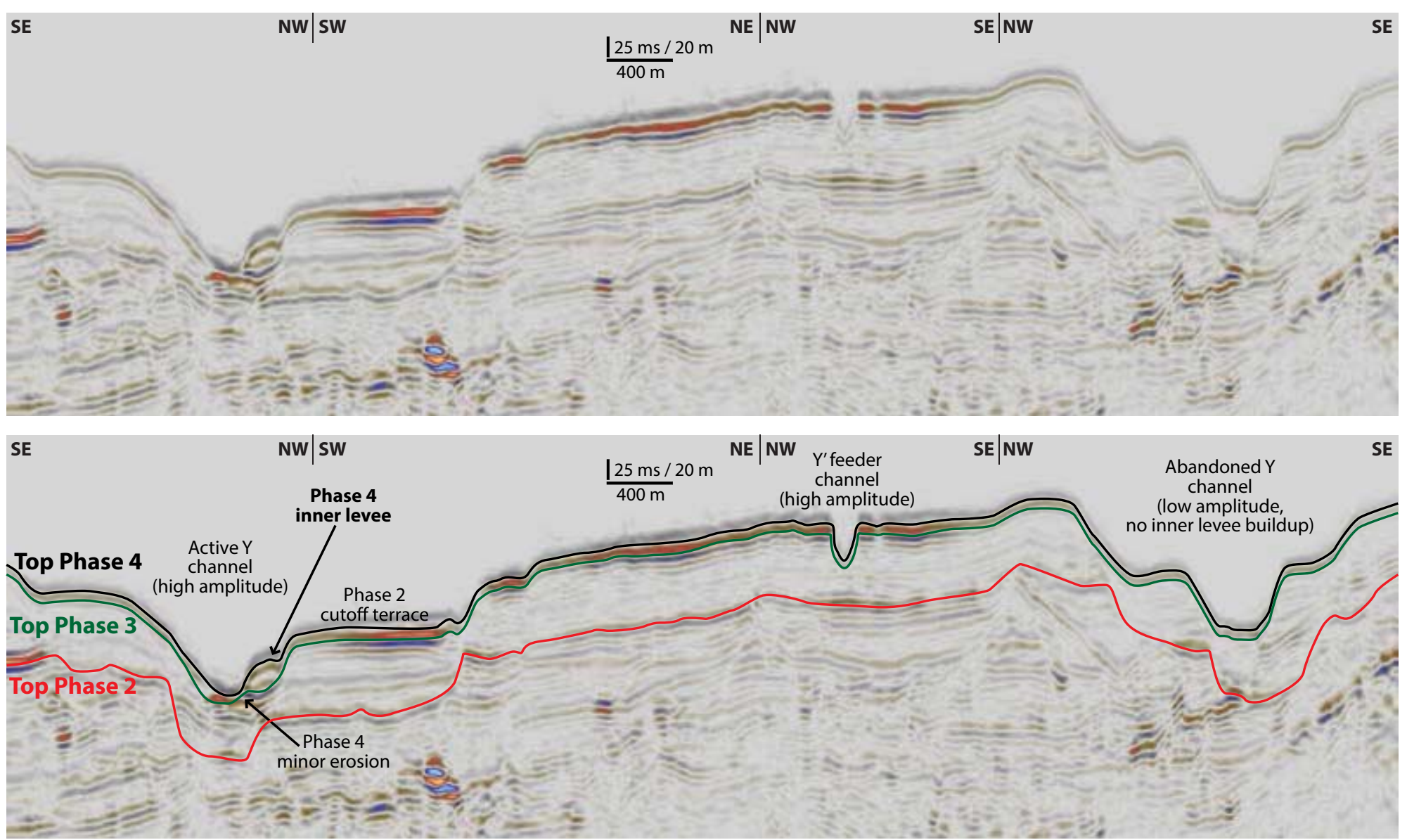



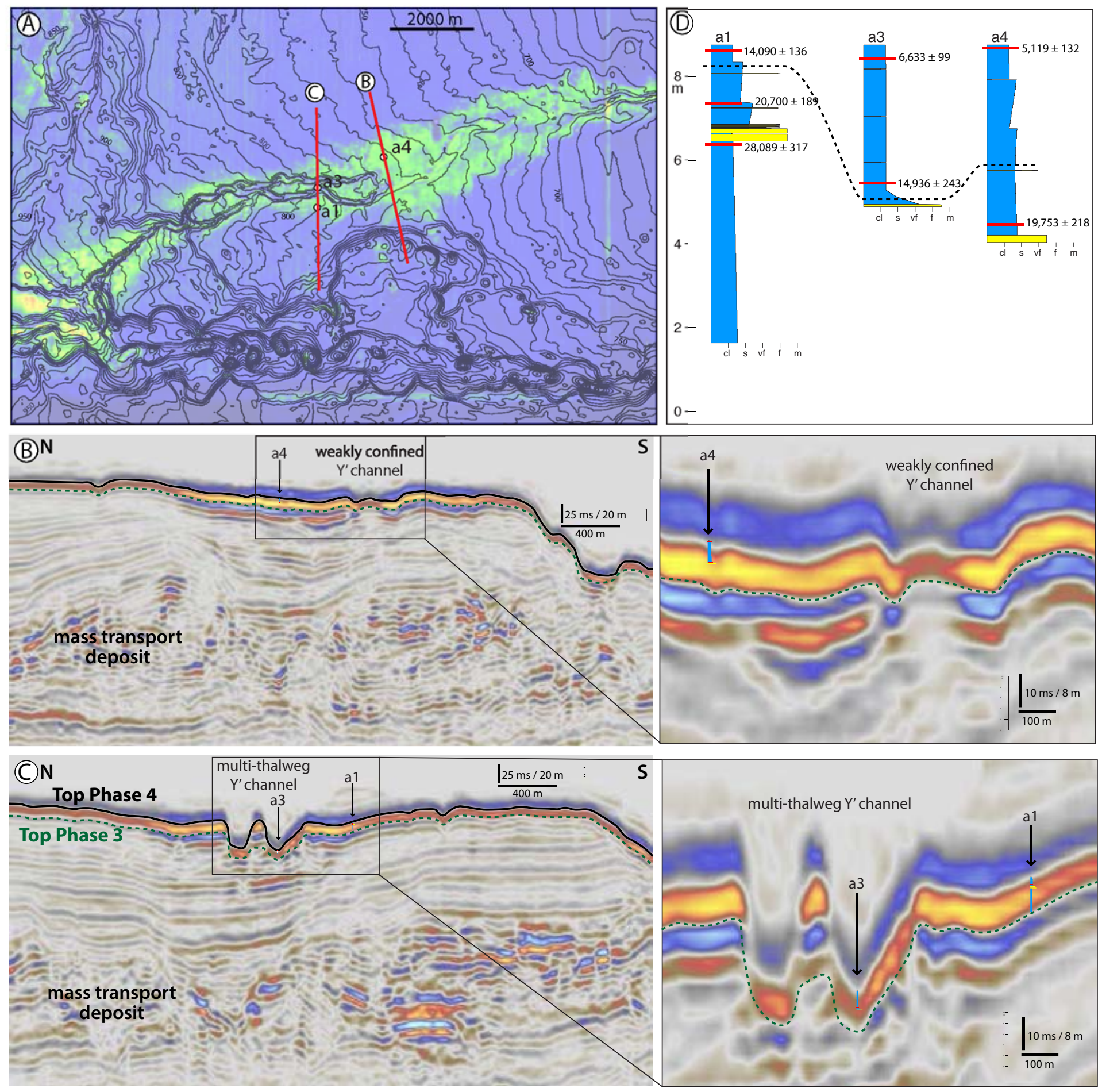

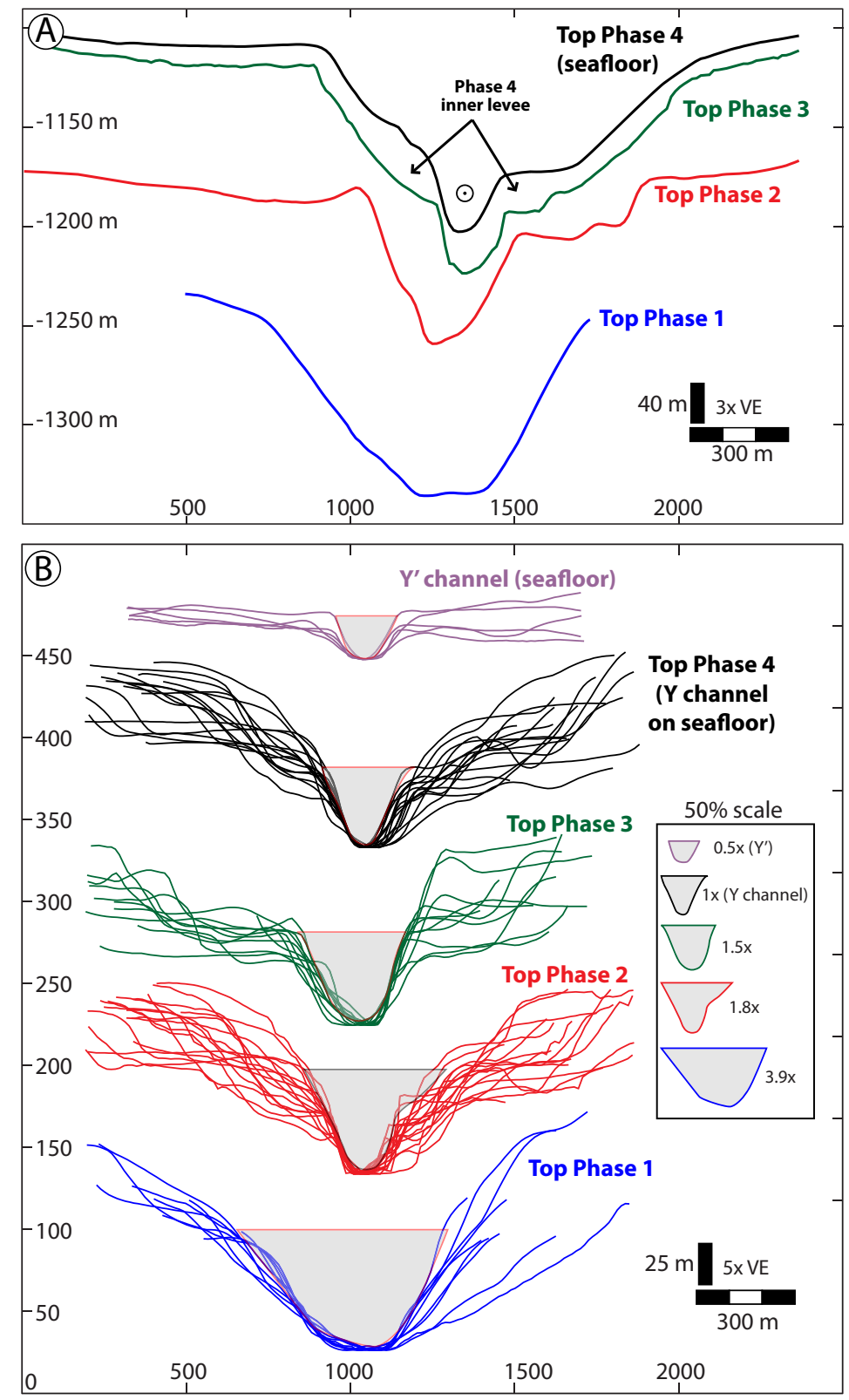

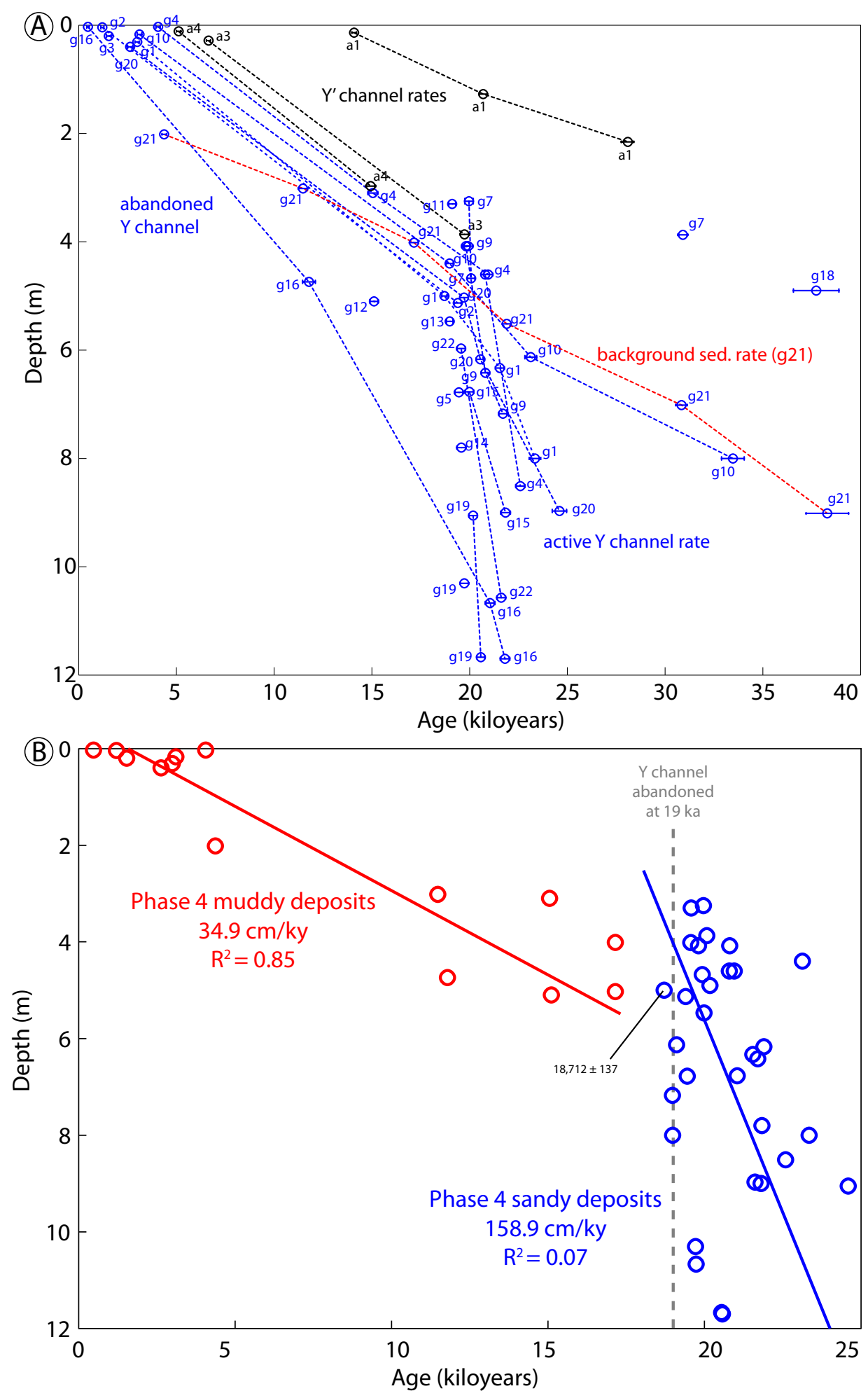


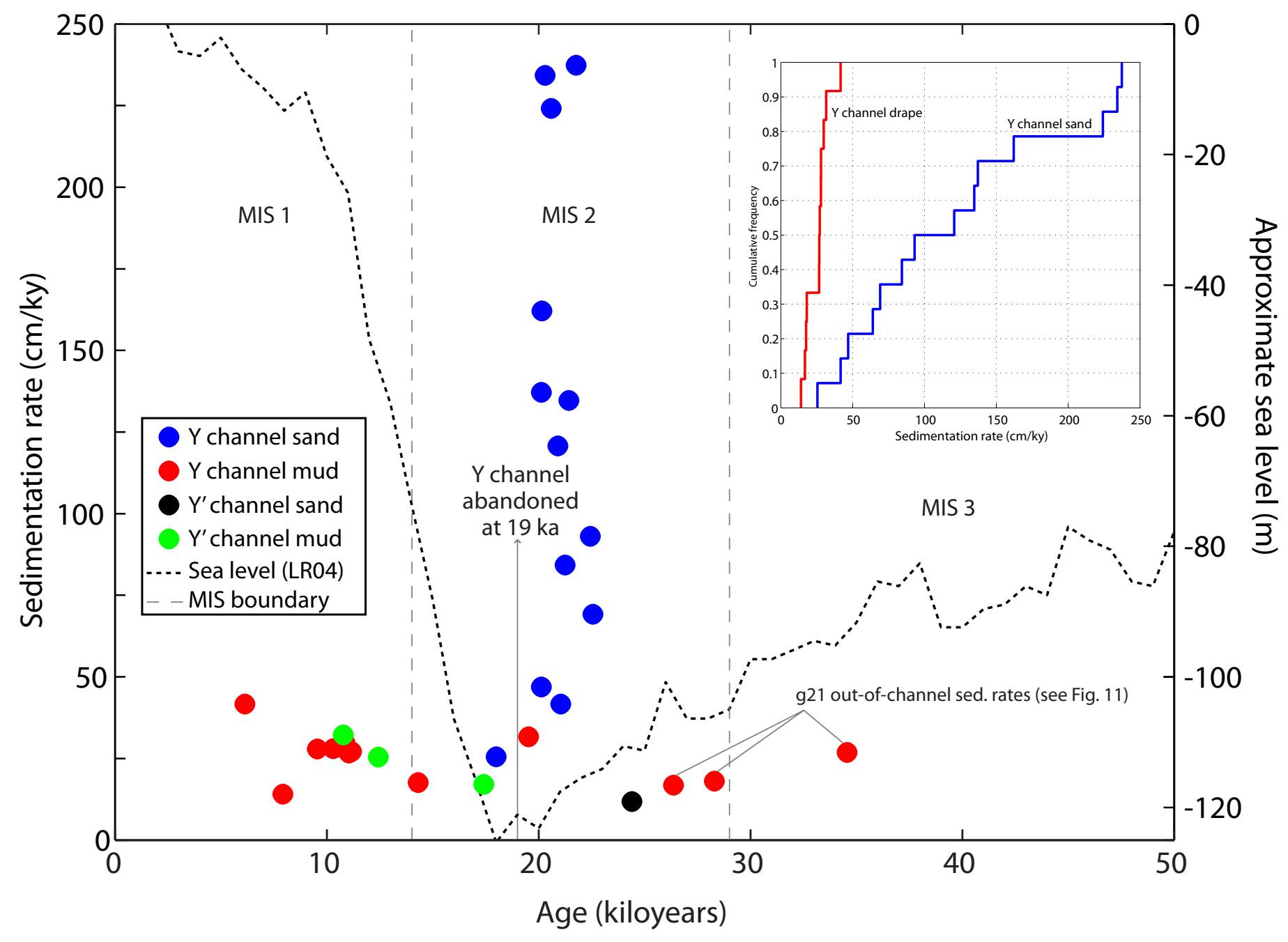



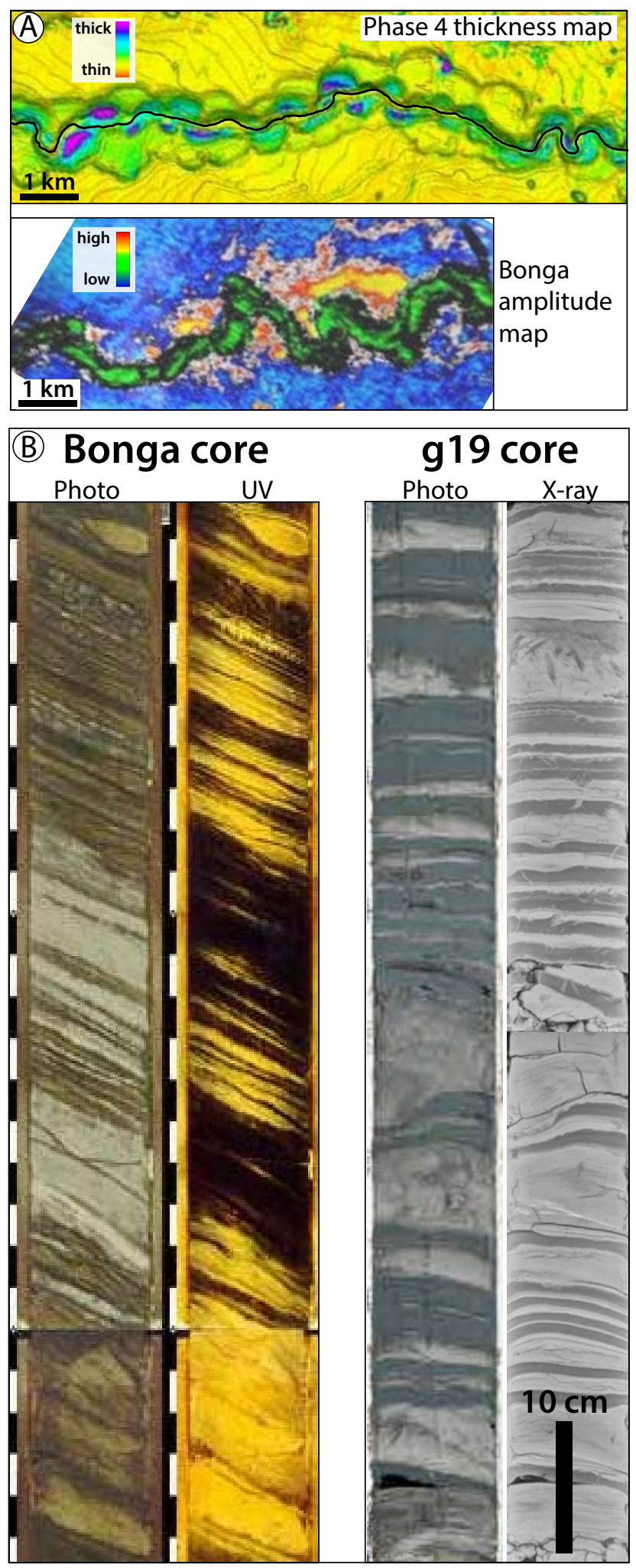


\begin{tabular}{|c|c|c|c|c|c|c|c|c|c|c|c|}
\hline sample name & CAMS\# & $\delta^{13} \mathrm{C}$ & fraction of Modern & \pm & $\Delta^{14} \mathrm{C}$ & \pm & ${ }^{14} \mathrm{C}$ age & $\begin{array}{c} \pm \\
(\text { measur } \\
\text { ement } \\
\text { error) }\end{array}$ & $\begin{array}{l}\text { Calibrated } \\
\text { age }\end{array}$ & $\begin{array}{l}(+) 2 \sigma \\
\text { error }\end{array}$ & $\begin{array}{l}(-) 2 \sigma \\
\text { error }\end{array}$ \\
\hline ana $110-16 \mathrm{~cm}$ & 160743 & 0 & 0.208279567 & 0.000825428 & -791.7204326 & 0.825428058 & 12605 & 35 & 14090 & 125 & 136 \\
\hline ana $1124-130 \mathrm{~cm}$ & 160744 & 0 & $\begin{array}{l}0.112250556 \\
0.175021\end{array}$ & 0.000618727 & $\frac{-887.7494443}{8.764014}$ & $\begin{array}{l}0.618726701 \\
.5120900\end{array}$ & 17570 & 45 & 20700 & 189 & 167 \\
\hline ana $1212-218 \mathrm{~cm}$ & 160745 & 0 & & 0.000541088 & -952.4669991 & & 24470 & 100 & 28089 & 317 & 273 \\
\hline ana $326-31 \mathrm{~cm}$ & 162740 & 1 & 0.462605947 & 0.001647325 & -537.3940528 & 1.647324899 & 6190 & 30 & 6633 & 92 & 99 \\
\hline ana $3294-300 \mathrm{~cm}$ & 162741 & 1 & 0.19854447 & 0.000894277 & -801.4555304 & 0.894276543 & 12985 & 40 & 14936 & 204 & 243 \\
\hline ana $4383-389 \mathrm{~cm}$ & 162742 & 1 & 0.124008867 & 0.000781691 & -875.9911331 & 0.781691287 & 16770 & 60 & 19753 & 218 & 197 \\
\hline ana $48-14 \mathrm{~cm}$ & $\frac{162739}{16272}$ & 1 & $\begin{array}{l}0.548686666 \\
0.101722 \\
0\end{array}$ & 0.001919564 & -451.313334 & 1.919564491 & 4820 & 30 & 5119 & 132 & 130 \\
\hline $\begin{array}{l}\text { grand } 128-34 \mathrm{~cm} \\
\text { orand 1 447-503 } \mathrm{cm}\end{array}$ & $\begin{array}{l}162723 \\
16362\end{array}$ & $\frac{1}{0}$ & $\begin{array}{l}0.671942733 \\
0139017628\end{array}$ & 0.002221878 & $\frac{-328.0572674}{80002324}$ & 2.221877571 & $\frac{3195}{1580}$ & $\frac{30}{55}$ & 2994 & 114 & 115 \\
\hline grand $1630-636 \mathrm{~cm}$ & $\frac{165382}{163683}$ & $\frac{0}{0}$ & $\begin{array}{l}0.13901628 \\
0.103884703\end{array}$ & $\frac{0.0008668646}{0.000602334}$ & $\frac{-860.9823724}{-896.1152973}$ & $\frac{0.866864264}{0.00233587}$ & $\frac{15850}{18190}$ & $\frac{55}{50}$ & $\frac{18712}{21547}$ & $\frac{118}{235}$ & $\frac{137}{210}$ \\
\hline grand $1797-803 \mathrm{~cm}$ & 162724 & 1 & 0.085077564 & 0.000770814 & -914.9224363 & $\begin{array}{l}0.00253501 \\
0.770813732\end{array}$ & $\frac{1010}{19790}$ & 80 & 23341 & 264 & 293 \\
\hline grand $1014-20 \mathrm{~cm}$ & 162731 & 1 & 0.664735331 & 0.002274016 & -335.2646692 & 2.274016454 & 3280 & 30 & 3111 & 100 & 115 \\
\hline grand $10437-443 \mathrm{~cm}$ & 162732 & 1 & 0.134036437 & 0.000851004 & -865.9635635 & 0.851004315 & 16140 & 60 & 18975 & 185 & 141 \\
\hline grand $10610-616 \mathrm{~cm}$ & 162733 & 1 & 0.087123694 & 0.000761292 & -912.8763061 & 0.761292268 & 19600 & 80 & 23128 & 303 & $\frac{253}{253}$ \\
\hline grand $10797-803 \mathrm{~cm}$ & 163640 & 0 & 0.024870216 & 0.00072572 & -975.1297836 & 0.725719844 & 29670 & 240 & 33468 & 448 & \\
\hline grand $11327-333 \mathrm{~cm}$ & 163641 & 0 & 0.132098074 & 0.000821007 & -867.9019259 & 0.821007183 & 16260 & 50 & 19108 & 177 & 170 \\
\hline grand $12507-513 \mathrm{~cm}$ & 163642 & 0 & 0.196160206 & 0.000892045 & -803.8397936 & 0.892045185 & 13085 & 40 & 15108 & 159 & 226 \\
\hline grand $13544-550 \mathrm{~cm}$ & 163643 & 0 & 0.133933052 & 0.000803139 & -866.0669479 & 0.803138833 & 16150 & 50 & 18983 & 168 & 124 \\
\hline grand $14777-783 \mathrm{~cm}$ & 163644 & 0 & 0.126307275 & 0.000796078 & -873.6927255 & 0.796077695 & 16620 & 60 & 19575 & 233 & 206 \\
\hline grand $15674-680 \mathrm{~cm}$ & 162734 & 1 & 0.120892296 & 0.00081292 & -879.1077039 & 0.812920003 & 16970 & 60 & 19988 & 203 & 231 \\
\hline grand $15897-903 \mathrm{~cm}$ & 163645 & 0 & 0.100845601 & 0.000779948 & -899.1543988 & 0.779947571 & 18430 & 70 & 21835 & 239 & 249 \\
\hline grand $160-6 \mathrm{~cm}$ & 162735 & 1 & 0.900621064 & 0.003703985 & -99.37893569 & 3.703985379 & 840 & 35 & 474 & 52 & 62 \\
\hline grand $161064-1070 \mathrm{~cm}$ & 163646 & 0 & 0.108495703 & 0.000809772 & -891.5042966 & 0.809771598 & 17840 & 60 & 21045 & 248 & 219 \\
\hline grand $161167-1173 \mathrm{~cm}$ & 163647 & 0 & & 0.000802777 & & & $\frac{1740}{18410}$ & 70 & 21810 & 231 & 243 \\
\hline grand $16471-477 \mathrm{~cm}$ & 162736 & 1 & 0.269354767 & 0.001195799 & -730.6452325 & 1.195798853 & 10535 & 40 & 11784 & 206 & 325 \\
\hline grand $17765-770 \mathrm{~cm}$ & 162737 & 1 & & 0.000715138 & -998.2044288 & 0.715137579 & 50800 & 3200 & too old & & \\
\hline grand $18487-493 \mathrm{~cm}$ & 163648 & 0 & & 0.000729435 & -985.2487355 & 0.729435329 & 33870 & 400 & 37729 & 938 & 1163 \\
\hline grand $18907-913 \mathrm{~cm}$ & 163649 & 0 & 0.000506934 & 0.00071524 & -999.4930661 & 0.71523997 & $>50200$ & & too old & & \\
\hline grand $191029-1032 \mathrm{~cm}$ & 163651 & 0 & & 0.000800357 & -875.7517355 & 0.800357222 & 16750 & 60 & 19730 & 222 & 191 \\
\hline grand $191164-1170 \mathrm{~cm}$ & 162769 & 1 & & 0.000802483 & -886.2863542 & 0.802483291 & 17460 & 60 & 20572 & 203 & 210 \\
\hline grand $19902-909 \mathrm{~cm}$ & 163650 & 0 & $\begin{array}{l}0.118500697 \\
.0507\end{array}$ & 0.000788135 & -881.4993026 & 0.788135183 & 17130 & 60 & 20176 & 216 & 202 \\
\hline $\begin{array}{r}\text { grand } 20-8 \mathrm{~cm} \\
\text { orand } 250-16 \mathrm{~cm}\end{array}$ & $\frac{160756}{16078}$ & $\frac{0}{0}$ & $\frac{0.815575536}{0.128716401}$ & $\begin{array}{l}0.00294303 \\
0.0068522\end{array}$ & $\frac{-184.4244638}{-8812835987}$ & 2.943030103 & $\frac{1640}{1640}$ & $\frac{30}{45}$ & $\frac{1209}{19396}$ & $\frac{67}{164}$ & $\frac{78}{176}$ \\
\hline grand $2037-43 \mathrm{~cm}$ & $\frac{100270}{162770}$ & $\frac{0}{1}$ & & $\begin{array}{l}0.0000009924 \\
0.002495764\end{array}$ & $\frac{-0 / 1.2055981}{-299.2370832}$ & $\begin{array}{l}0.0059292 \\
2.495764173 \\
\end{array}$ & $\frac{1640}{2855}$ & $\frac{45}{30}$ & & $\frac{164}{83}$ & $\frac{116}{134}$ \\
\hline grand $20500-506 \mathrm{~cm}$ & 162771 & 1 & & $\begin{array}{l}0.006497104 \\
0.000726864\end{array}$ & $\frac{-29.257002}{-875.5753944}$ & $\frac{2.49 / 40113}{0.726864461}$ & $\frac{20 J 3}{16740}$ & 50 & & $\frac{53}{213}$ & 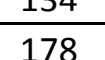 \\
\hline grand $20614-620 \mathrm{~cm}$ & 162772 & 1 & & $\begin{array}{l}0.0012000794 \\
0.000719936\end{array}$ & -885.8723905 & $\begin{array}{l}0.120000+401 \\
0.719935628\end{array}$ & $\frac{10740}{17440}$ & $\frac{50}{60}$ & 20548 & $\frac{213}{195}$ & $\frac{125}{225}$ \\
\hline grand $20894-900 \mathrm{~cm}$ & 162773 & 1 & & 0.000738584 & -925.5156428 & 年 & $\frac{17+40}{20860}$ & 80 & 24595 & $\frac{367}{367}$ & $\frac{285}{285}$ \\
\hline grand $21200-203 \mathrm{~cm}$ & 160734 & 0 & & 0.002057922 & -411.67693 & 2.057921953 & 4260 & 30 & 4372 & 106 & \\
\hline grand $21300-303 \mathrm{~cm}$ & 163652 & 0 & 33973737 & 0.001109758 & -726.0262625 & 1.109757994 & $\frac{1060}{10400}$ & $\frac{35}{35}$ & 11475 & $\frac{247}{247}$ & $\frac{208}{208}$ \\
\hline Grand $21340-343 \mathrm{~cm}$ & 165172 & 0 & 55720805 & 0.000929249 & -764.279195 & 0.929249306 & 11610 & 35 & 13104 & 123 & 150 \\
\hline grand $21400-403 \mathrm{~cm}$ & 1636 & 0 & 0.164377497 & 0.000853126 & -835.622503 & 0.853125506 & 14505 & 45 & 17152 & 234 & 193 \\
\hline grand $21550-553 \mathrm{~cm}$ & 1607 & 0 & & 0.000606211 & -899.7397296 & 0.606210697 & 18480 & 50 & 21898 & 226 & 209 \\
\hline Grand $2160-63 \mathrm{~cm}$ & 165171 & 0 & 0.659354751 & 0.002323563 & -340.6452488 & 2.32356323 & 3345 & 30 & 3202 & 117 & 102 \\
\hline Grand $21630-633 \mathrm{~cm}$ & 165173 & 0 & 111469 & 0.000524158 & -927.94 & 0.524157764 & 21130 & 60 & & 258 & 381 \\
\hline grand $21700-$ & 16365 & 0 & & 0.000732002 & -965.3 & 0.7320 & 27000 & 170 & & 257 & 292 \\
\hline Grand $21770-7$ & 1651 & 0 & & 0.002 & & 2.5830 & 30320 & 910 & & 1719 & 2179 \\
\hline Grand $21830-\varepsilon$ & 1651 & 0 & & 0.0004 & -979.4 & & 31200 & 190 & & 381 & 415 \\
\hline grand 21900 & 160736 & 0 & & 0.000 & -985.9 & & 34260 & 310 & & 712 & 1089 \\
\hline grand 22 1054- & 163 & 0 & & & & 0.7701 & 18240 & 60 & 615 & 221 & 225 \\
\hline grand 22594 & 1634 & 0 & & & & 0.7992 & 16610 & 60 & 19563 & 227 & 214 \\
\hline grand $317-23$ & 1636 & 0 & & & & & 198 & 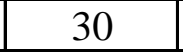 & & 88 & 117 \\
\hline grand 4 & 160737 & 0 & & 0.002 & & & 404 & 3 & & 111 & 110 \\
\hline grand 430 & 162725 & 1 & & & & 0.864474038 & 1305 & 40 & & 162 & 254 \\
\hline grand 44 & 162726 & 1 & & 0.000767566 & -890.5088559 & 0.767566316 & $1777^{2}$ & 60 & 20948 & 240 & 230 \\
\hline grand 44 & 162774 & 1 & & 0.0007 & & 0.773617668 & 17650 & & 20795 & 211 & 201 \\
\hline grand $4848-854 \mathrm{~cm}$ & $\frac{162727}{16260}$ & 1 & $\frac{0.092232893}{0.208715}$ & 0.000751329 & $\frac{-907.7671066}{8071128107}$ & 0.751328874 & $\frac{19150}{1650}$ & 70 & 22593 & 236 & $\frac{175}{214}$ \\
\hline grand $56 / 5-681 \mathrm{~cm}$ & 160079 & 0 & $\frac{0.1210015}{012021694}$ & $\frac{0.0001054}{0.0070164}$ & 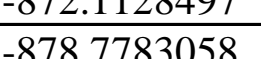 & $\frac{0.816340089}{0706164044}$ & $\frac{16200}{16950}$ & $\frac{60}{50}$ & $\frac{19491}{19966}$ & $\frac{175}{186}$ & 214 \\
\hline grand $7384-390 \mathrm{~cm}$ & 160739 & 0 & 0.42182001 & 0.00538519 & -966.8170994 & 0583519159 & 27120 & 130 & 3090 & $\frac{100}{202}$ & $\frac{210}{217}$ \\
\hline grand $7466-469 \mathrm{~cm}$ & 160740 & 0 & 011978346 & 0.000633574 & -8802165395 & 0603574148 & 17045 & 45 & $\frac{20076}{2007}$ & 181 & $\frac{215}{185}$ \\
\hline grand $9405-411 \mathrm{~cm}$ & 162728 & 1 & 0.121702274 & 0.000766295 & -878.2977263 & 0766294962 & 16920 & 60 & $\frac{19927}{1927}$ & $\frac{108}{198}$ & $\frac{138}{238}$ \\
\hline grand $9405-411 \mathrm{~cm}$ & 162775 & $\frac{1}{1}$ & 0.123134855 & 0.00082028 & $\frac{-87.68651451}{-876}$ & 0.120280308 & $\frac{1620}{1680}$ & 60 & 19807 & 210 & $\frac{210}{220}$ \\
\hline grand $9639-645 \mathrm{~cm}$ & 162729 & 1 & $\frac{0.131015634}{0.1101036}$ & $\frac{0.000767501}{0.007675}$ & 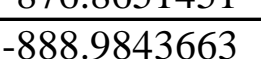 & $\frac{1.0 .076000222}{0.765082}$ & 17660 & 60 & 20806 & $\frac{214}{214}$ & 201 \\
\hline grand $9715-720 \mathrm{~cm}$ & 162730 & 1 & 0.102308451 & 0.000755163 & -897.6915489 & 0.755162641 & 18310 & 60 & 21702 & 193 & $\frac{226}{226}$ \\
\hline
\end{tabular}

